\title{
Correlation between carcass conformation and fat cover degree, and muscle fatty acid profile of yearling bulls depending on breed and $m h$-genotype
}

\author{
N. Aldai ${ }^{\text {a,* }}$, A.I. Nájera ${ }^{b}$, A. Martínez $^{\text {a }}$, R. Celaya ${ }^{a}$, K. Osoro ${ }^{\text {a }}$ \\ a Área de Sistemas de Producción Animal, Servicio Regional de Investigación y Desarrollo Agroalimentario (SERIDA), \\ Apdo. 13 - 33300 Villaviciosa, Asturias, Spain \\ b Área de Tecnología de los Alimentos, Facultad de Farmacia, Universidad del País Vasco - Euskal-Herriko Unibertsitatea (UPV-EHU), \\ Paseo de la Universidad 7, 01006 Vitoria-Gasteiz, Spain
}

Received 6 April 2006; received in revised form 4 August 2006; accepted 14 September 2006

\begin{abstract}
The objective was to study the relationships between the actual European beef carcass classification scale, which classifies carcasses with regard to conformation and degree of fat cover scores, and muscle fat quality, depending on breed and $m h$-genotype. For this purpose samples from 100 yearling bulls from "Asturiana de los Valles" (24 AV $(m h / m h), 26 \mathrm{AV}(m h /+), 25 \mathrm{AV}(+/+))$ and "Asturiana de la Montaña" (25 AM) were analysed. The results of the study showed that breed or genotype affect carcass measurement scores and muscle fatty acid profile through its important effect on animal overall fatness. Homozygous doublemuscled animals produced carcasses with high conformation and low intramuscular (IM) fat content. While early-maturing and rustic AM animals produced low carcass yield and high IM fat content. The other genotypes $(\mathrm{mh} /+,+/+)$ showed, in general, intermediate characteristics. Referring to correlations, carcass conformation was negatively related to saturated (SFA) $(r=-0.69$, $P<0.001)$ and monounsaturated fatty acid (MUFA) $(r=-0.69, P<0.001)$ groups, and positively to polyunsaturated (PUFA) $(r=0.72), \mathrm{n}-6(r=0.72), \mathrm{n}-3(r=0.71)$ and unsaturated fatty acid (UFA) $(r=0.69)$ groups, being all of them significant $(P<0.001)$. However, carcass degree of fat cover was positively related to SFA $(r=0.53, P<0.001)$ and MUFA $(r=0.62, P<0.001)$, and negatively to PUFA $(r=-0.61), \mathrm{n}-6(r=-0.60), \mathrm{n}-3 \quad(r=-0.62)$ and UFA $(r=-0.53)$ groups, being all of them significant. Moreover, simple and low-cost prediction equations were calculated for a rapid and sufficiently accurate fatty acid group (SFA, MUFA, PUFA, n-6, n-3, UFA) estimation $\left(R^{2}>0.46, P<0.001\right)$. In general, meat obtained from double-muscled animals display a more appropriate IM fatty acid profile from the nutritional point of view according to actual recommendations, but it could happen the disability of these lean animals to deposit sufficient IM fat to ensure consumer overall liking or acceptability.
\end{abstract}

(C) 2006 Elsevier B.V. All rights reserved.

Keywords: Beef; Genotype; Muscular hypertrophy; Carcass quality; Meat quality; Fatty acids

\footnotetext{
* Corresponding author. Tel.: +34 98 5890066; fax: +34 985891854. E-mail addresses: knbaleln@vc.ehu.es, naldai@serida.org (N. Aldai)
}

\section{Introduction}

In Europe, the Regulations No 1208/81 (OJEC, 1981a) and 2930/81 (OJEC, 1981b) and their amending Regulations No 1026/91 (OJEC, 1991a) and 2237/91 
(OJEC, 1991b) determine the "Community Scale for the Classification of Carcasses of Adult Bovine Animals" as the rule which standardises and gives transparency on carcass grading. This system classifies carcasses with regard to two parameters: carcass conformation and degree of fat cover. In Spain, the law (BOE, 2003) complements carcass grade described by the European Regulation establishing selling categories of beef meat regarding age and sex (veal, yearling bull, young bull or heifer, fattened bull, bullock, cow and bull). Also, retail meat cuts are officially classified in five different categories depending on the muscles involved in each cut. In other words, beef quality criteria for trades are mainly focused on those parameters directly related to carcass characteristics, and these parameters determine the economic value of beef (Horcada, 2001). That is why producers and butchers are usually more interested in carcass quality defined by a good carcass conformation, low fat level, and high proportion of desirable retail cuts. Therefore, meat price in the market is positively related to carcass conformation, but not necessarily with a good sensorial quality (Osoro et al., 2003). Nevertheless, actual consumer tends to be more concerned about meat quality and its consistency in terms of sensorial attributes (i.e., tenderness, flavour, colour), healthiness (i.e., fat quantity and quality), and safety (i.e., Escherichia coli O157:H7, Bovine Spongiform Encephalopathy). As a result of this, beef quality should be a combination of carcass quality plus meat quality.

If it is not the case of the European carcass grading system, the degree of marbling (visible intramuscular (IM) fat) has been corroborated to be a good criteria to evaluate meat quality in some other countries' grading systems (i.e. USDA Quality Grades in USA, MSA System in Australia). In particular, Japanese grading standards (for beef and pork) include also the quality of the fat of carcasses as an important aspect to evaluate.

Intramuscular fat, composed by marbling cells (fat cells located between bundles of muscle fibres) and fat within muscle cells (largely comprised by the lipid in cell membrane components, together with that present in vesicles as a lipid droplet) (Gandemer, 1999), firstly, influences several sensorial attributes like flavour, as lubrication effect may improve juiciness and indeed its flavour through a complex interaction between components of fat and lean, and tenderness, by reducing bulk density and decreasing the strength of the connective tissue (Wood et al., 1997). Moreover, it protects meat from drying out during cooking. Secondly, IM fat cannot be considered in isolation from its health effects and related consumer concerns and its fatty acid (FA) profile has to be taken into consideration (Mazier and Jones,
1991; Simopoulos, 1991, 2002; Ulbricht and Southgate, 1991). Many studies have shown that fat partitioning (in the sense of amount and distribution) among the depots is influenced by several factors such as breed or genotype (Callow, 1962; Wright and Russel, 1984; HuertaLeidenz et al., 1993), sex or physiological status (Kazala et al., 1999; Malau-Aduli et al., 2000), age or live weight (Truscott et al., 1983; Rule et al., 1995), feeding (Mandell et al., 1997; Bas and Morand-Fehr, 2000) and anatomical location (Hood and Allen, 1975; Truscott et al., 1983), and that FA composition could be also influenced by the aforementioned factors and their interactions mainly related to animal's fat content (Nürnberg et al., 1998, 1999; De Smet et al., 2004).

All-in-all, and taking into account the lack of relation between the actual European beef carcass classification scale and meat quality attributes, and especially with fat quality, the aim of this study was to evaluate the reliability of carcass measurement scores taken at abattoir level (conformation and fat cover degree) to predict the FA profile of meat through several genotypes characterised with a wide range of carcass measurement scores. For this purpose FA profile of two Asturian local breeds (Asturiana de los Valles (AV) and Asturiana de la Montaña (AM)) and three genotypes of the first one depending on the presence or absence of muscular hypertrophy gene $(\mathrm{AV}(m h / m h), \operatorname{AV}(m h /+), \operatorname{AV}(+/+))$ considered as four biological types or genotypes, were, firstly, compared.

\section{Materials and methods}

\subsection{Animals, management and diet composition}

One hundred yearling bulls from "Asturiana de los Valles" (AV, $n=75$ ), a beef breed adapted to extensive production systems, and "Asturiana de la Montaña" (AM, $n=25$ ), a beef breed characterised by small to medium-sized rustic animals adapted to less favoured mountain areas, were studied during three consecutive years (2001/03) with similar animal repartition per year. Blood sample from AV animals was analysed to determine the presence of the 11-bp deletion in the coding sequence of the myostatin gene causing doublemuscling in cattle (Grobet et al., 1998) and classify animals into three groups: AV double-muscled $(\mathrm{mh} / \mathrm{mh}$, $n=24)$, AV heterozygous $(m h /+, n=26)$ and AV normal $(+/+, n=25)$. AM animals lack the mutation responsible for double-muscling $(n=25)$.

Calves were suckled by their mothers from birth (winter) to weaning (early autumn). After a postweaning adjustment period of about 15 days, they were fattened 
by feeding concentrate meal ( $84 \%$ barley meal, $10 \%$ soya meal, $3 \%$ vegetable fat (soya oil), 3\% minerals, vitamins and oligoelements) and barley straw, both ad libitum (typical Spanish fattening diet), in the housing facilities of the research Institute (SERIDA). Table 1 shows the chemical composition and the FA profile of the experimental concentrate meal. Determination of final dry matter and crude ashes were conducted by drying out and incineration (Van Es and Van Der Meer, 1980; Van Der Meer, 1983), crude protein was conducted by Kjeldahl method (TECATOR, 1995, 2001), crude fat was conducted by Soxhlet extraction (TECATOR, 1991), acid detergent fibre determination was conducted according to Goering and Van Soest (1970) and neutral detergent fibre was conducted according to Robertson and Van Soest (1981) and Van Soest et al. (1991). The FA profile was determined by gas-liquid chromatography based on a modification of the Elmore et al. (1999) method as outlined in Aldai et al. (2005) and validated in Aldai et al. (2006b).

\subsection{Carcass measurements and sampling}

Animals were slaughtered on reaching an average live weight of $542 \pm 4 \mathrm{~kg}$ for the AV breed and $491 \pm 6 \mathrm{~kg}$ for the AM breed. Slaughtering was performed in a commercial abattoir according to standard procedures. Yearling bulls were weighed twice (on the day prior to slaughter and on the day of slaughter) to get the final average live weight. After slaughtering and dressing, hot carcass weight was recorded and carcasses chilled at $3{ }^{\circ} \mathrm{C}$. Cold carcass weight was calculated subtracting $2 \%$ to the hot carcass weight and carcass yield proportion was calculated as the relation between live weight at slaughter and cold carcass weight.

Table 1

Chemical and major fatty acid composition of the concentrate meal

\begin{tabular}{lc}
\hline & Concentrate \\
\hline Chemical composition (\%) $^{\mathrm{a}}$ & \\
Crude protein & 14.62 \\
Crude fat & 5.69 \\
Crude ash & 4.50 \\
Acid detergent fibre & 5.18 \\
Neutral detergent fibre & 16.73 \\
& \\
Fatty acid composition (\%) & \\
C16:0 & \\
C18:0 & 16.28 \\
C18:1 1 cis 9 & 1.75 \\
C18:2n-6 & 13.02 \\
C18:3n-3 & 60.38 \\
\hline
\end{tabular}

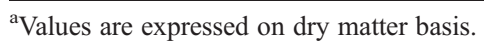

${ }^{\mathrm{b}}$ Percentage of total fatty acids quantified.
Twenty-four hours post-mortem, carcasses were classified by visual assessment on conformation and fat cover degree by the same trained and experienced evaluator. For conformation, development of carcass profiles, in particular the essential parts (round, back, shoulder) was taken into consideration according to EUROP classification (E: excellent, U: very good, R: good, O: fair, P: poor), and for fat cover degree the amount of fat on the outside of the carcass and in the thoracic cavity was taken into account using a classification range from 1 to 5 (1: low, 2: slight, 3: average, 4: high, 5: very high). Each level of both scales (conformation and degree of fat cover) was subdivided in 3 sub-classes (i.e. conformation: $\mathrm{R}^{+}, \mathrm{R}, \mathrm{R}^{-}$and fat cover: $3^{+}, 3,3^{-}$) to a transformed scale ranging from 1 to 15 , being 15 the best conformation and the thickest fat cover (OJEC, 1981a,b, 1991a,b).

The part of the rib joint comprised between the 6th and 8 th ribs of the left half carcass was extracted by cutting the length of the bone at the limit of the serratus dorsalis muscle (Robelin and Geay, 1975) and transported to the laboratory. Then, the 6th rib was excised, total weight recorded, and the longissimus thoracis (LT) muscle separated and weighed while the rest of the rib was frozen at $-20{ }^{\circ} \mathrm{C}$ until dissection. It was thawed overnight at $4{ }^{\circ} \mathrm{C}$ and dissected into lean, subcutaneous (SC) fat, intermuscular (IT) fat, and bone. Other tissues (blood vessels, ligaments, etc.) were recorded as bone. The 6th rib dissection was used as a predictor of the carcass composition (Oliván et al., 1999).

The LT steak of the 8th rib was dissected, vacuum packed and frozen at $-80{ }^{\circ} \mathrm{C}$ at $24 \mathrm{~h}$ post-mortem for subsequent fat content and FA analysis.

\subsection{Muscle fat content and fatty acid profile}

Muscle or IM fat percentage was determined by NIRS (Oliván et al., 2002) calibrated (Pretreatment: SNV-DT, Standard error of calibration: $0.344, R^{2}=0.958$ ) by reference to a Soxhlet fat extraction method (ISO 1443-1973).

For FA profile determination, duplicate $1 \mathrm{~g}$ muscle tissue was saponified in $6 \mathrm{~mL} 5 \mathrm{M} \mathrm{KOH}$ in methanol/ water $(50: 50, \mathrm{v} / \mathrm{v})$ at $60^{\circ} \mathrm{C}$ for $1 \mathrm{~h}$, and the extracted FAs were methylated using trimethylsilyl-diazomethane in methanol:toluene $(2: 1, \mathrm{v} / \mathrm{v})$ at $40^{\circ} \mathrm{C}$ for $10 \mathrm{~min}$ based on a modification of the method by Elmore et al. (1999) as outlined in Aldai et al. (2005) and validated in Aldai et al. (2006b).

Obtained FA methyl esters were identified according to similar peak retention times using standards (SigmaAldrich), and quantified using the chromatographic 
peak area according to the internal standard method (free $\mathrm{C} 21: 0$ ) with its addition prior to saponification. The response factors of the individual FAs were previously calculated.

Selected abbreviations: FA: fatty acid; saturated FA: $\mathrm{SFA}=\mathrm{C} 10: 0+\mathrm{C} 12: 0+\mathrm{C} 13: 0+\mathrm{C} 14: 0+\mathrm{C} 15: 0+\mathrm{C} 16: 0+$ $\mathrm{C} 17: 0+\mathrm{C} 18: 0+\mathrm{C} 19: 0+\mathrm{C} 20: 0+\mathrm{C} 22: 0 ;$ branched FA: $\mathrm{BFA}=i s o \mathrm{C} 15: 0+$ anteiso $\mathrm{C} 15: 0+i s o \mathrm{C} 16: 0+i s o \mathrm{C} 17: 0+$ isoC18:0; monounsaturated FA: $\mathrm{MUFA}=\mathrm{C} 14: 1$ cis $9+$ $\mathrm{C} 16: 1$ cis $9+\mathrm{C} 17: 1$ cis $10+\mathrm{C} 18: 1$ trans $+\mathrm{C} 18: 1$ cis $9+$ $\mathrm{C} 18: 1$ cis $11+\mathrm{C} 18: 1$ cis $12+\mathrm{C} 18: 1$ cis 13 ; polyunsaturated FA: PUFA $=\mathrm{C} 18: 2 \mathrm{n}-6+\mathrm{C} 18: 3 \mathrm{n}-6+\mathrm{C} 20: 2 \mathrm{n}-6+\mathrm{C} 20: 3 \mathrm{n}-$ $6+C 20: 4 n-6+C 22: 4 n-6+C 18: 3 n-3+C 20: 3 n-3+$ $\mathrm{C} 20: 5 \mathrm{n}-3+\mathrm{C} 22: 5 \mathrm{n}-3+\mathrm{C} 22: 6 \mathrm{n}-3+$ cis 9 , trans $11-\mathrm{CLA}+$ trans 10, cis12-CLA; n- 6 type of FA: n- $6=\mathrm{C} 18: 2 \mathrm{n}-6+$ C18:3n-6+C20:2n-6+C20:3n-6+C20:4n-6+C22:4n6; n-3 type of FA: n-3 =C18:3n-3+C20:3n-3 +C20:5n$3+\mathrm{C} 22: 5 \mathrm{n}-3+\mathrm{C} 22: 6 \mathrm{n}-3$; conjugated linoleic acid: $\mathrm{CLA}=$ cis 9 ,trans $11-\mathrm{CLA}+$ trans 10, cis 12-CLA; unsaturated FA: UFA =MUFA + PUFA; M/S=MUFA/SFA; P/ $\mathrm{S}=\mathrm{PUFA} / \mathrm{SFA} ; \mathrm{U} / \mathrm{S}=\mathrm{UFA} / \mathrm{SFA}$.

\subsection{Statistical analysis}

The statistical analysis was conducted using SPSS 11.5 (SPSS, Inc., 2002). ANOVA analysis was applied to study the differences on animal growth rates, carcass quality traits, rib composition, IM fat content and FA composition of muscle tissue between all animal groups as four independent genotypes or biological types: AV $(m h / m h), \mathrm{AV}(m h /+), \mathrm{AV}(+/+)$ and $\mathrm{AM}$. Year and genotype $\mathrm{x}$ year interaction were also included in the model. When analysis of variance gave significant differences between genotypes the LSD Post-Hoc test was applied (multiple comparison of means).

Correlation and multiple linear regression analysis, using stepwise as a variable adding method, were performed between carcass rapid and inexpensive measurements (conformation and degree of fat cover) and FA composition of IM fat.

Factor analysis, using principal components as an extraction method (eigenvalues over 1), was done including carcass measurements (conformation and degree of fat cover) and FA groups and ratios in the test.

\section{Results}

\subsection{Animal growth rates, carcass measurements, rib dissection and muscle fat content}

Animal fattening period, age and live weight at slaughter, carcass traits (weight, yield, conformation, fat cover degree, rib composition) and IM fat content are summarised in Table 2. Animals from AM breed showed a significantly $(P<0.001)$ longer fattening period than $\mathrm{AV}$ animals (251.9 days vs. mean value of 209.4 days $)$ with significantly $(P<0.001)$ lower daily live weight gains in comparison to AV animals $(1.1 \mathrm{~kg} /$ day vs. mean value of $1.4 \mathrm{~kg}$ /day). Moreover, AM animals were significantly $(P<0.001)$ older at slaughter (519.1 days $v s$. mean value of 460.2 days) and they also recorded significantly $(P<0.001)$ lighter slaughter and cold carcass weights, and consequently lower carcass yields $(54.7 \%$ for AM and $63.2 \%$ for $\mathrm{mh} / \mathrm{mh})$. On the other hand, the other three genotypes (AV breed) did not show significant differences between them, except for carcass weight and yield as double-muscled $(\mathrm{mh} / \mathrm{mh})$ animals showed significantly higher values than the others. According to carcass classification measurements, AM animals obtained the lowest conformation (7.5) and the highest fat cover scores (5.4) while doublemuscled animals obtained the best conformation (14.1) and the lowest fat cover score (2.3). Intermediate values were obtained by the other two genotypes.

Table 2

Least square means of growth rates, carcass quality traits, rib composition and muscle fat content for each genotype

\begin{tabular}{|c|c|c|c|c|c|c|}
\hline & $\begin{array}{l}\mathrm{AV} \\
(\mathrm{mh} / \mathrm{mh})\end{array}$ & $\begin{array}{l}\mathrm{AV} \\
(m h /+)\end{array}$ & $\begin{array}{l}\mathrm{AV} \\
(+/+)\end{array}$ & $\mathrm{AM}$ & s.e.m. & Sign. \\
\hline $\begin{array}{l}\text { Fattening } \\
\text { period (days) }\end{array}$ & $207.58^{\mathrm{a}}$ & $205.58^{\mathrm{a}}$ & $215.19^{\mathrm{a}}$ & $251.86^{\mathrm{b}}$ & 1.866 & $* * *$ \\
\hline $\begin{array}{l}\text { Daily gain } \\
\text { (kg/day) }\end{array}$ & $1.46^{\mathrm{b}}$ & $1.39^{\mathrm{b}}$ & $1.42^{\mathrm{b}}$ & $1.11^{\mathrm{a}}$ & 0.019 & $* * *$ \\
\hline $\begin{array}{l}\text { Age at } \\
\text { slaughter } \\
\text { (days) }\end{array}$ & $464.29^{\mathrm{a}}$ & $458.52^{\mathrm{a}}$ & $457.95^{\mathrm{a}}$ & $519.12^{\mathrm{b}}$ & 3.145 & $* * *$ \\
\hline LWS (kg) & $547.42^{\mathrm{b}}$ & $547.05^{\mathrm{b}}$ & $532.76^{\mathrm{b}}$ & $491.32^{\mathrm{a}}$ & 3.154 & $* * *$ \\
\hline CCW (kg) & $345.79^{d}$ & $315.45^{\mathrm{c}}$ & $302.30^{\mathrm{b}}$ & $268.67^{\mathrm{a}}$ & 2.077 & $* * *$ \\
\hline $\begin{array}{l}\text { Carcass } \\
\text { yield (\%) }\end{array}$ & $63.18^{\mathrm{c}}$ & $57.67^{\mathrm{b}}$ & $56.73^{\mathrm{b}}$ & $54.69^{\mathrm{a}}$ & 0.173 & $* * *$ \\
\hline Conformation & $14.12^{\mathrm{d}}$ & $10.71^{\mathrm{c}}$ & $9.95^{\mathrm{b}}$ & $7.51^{\mathrm{a}}$ & 0.106 & $* * *$ \\
\hline $\begin{array}{l}\text { Degree of } \\
\text { fat cover }\end{array}$ & $2.25^{\mathrm{a}}$ & $4.86^{\mathrm{b}}$ & $4.64^{\mathrm{b}}$ & $5.39^{\mathrm{c}}$ & 0.127 & $* * *$ \\
\hline \multicolumn{7}{|c|}{ Rib composition: } \\
\hline$\%$ Lean & $84.36^{\mathrm{c}}$ & $77.29^{\mathrm{b}}$ & $75.56^{\mathrm{a}}$ & $75.31^{\mathrm{a}}$ & 0.280 & $* * *$ \\
\hline$\%$ IT fat & $4.89^{\mathrm{a}}$ & $8.71^{\mathrm{b}}$ & $10.12^{\mathrm{c}}$ & $9.84^{\mathrm{c}}$ & 0.185 & $* * *$ \\
\hline$\%$ SC fat & $1.10^{\mathrm{a}}$ & $2.24^{\mathrm{b}}$ & $2.36^{\mathrm{b}}$ & $3.18^{\mathrm{c}}$ & 0.073 & $* * *$ \\
\hline$\%$ Total fat & $6.00^{\mathrm{a}}$ & $10.95^{\mathrm{b}}$ & $12.48^{\mathrm{c}}$ & $13.01^{\mathrm{c}}$ & 0.233 & $* * *$ \\
\hline$\%$ Bone & $9.64^{\mathrm{a}}$ & $11.76^{\mathrm{b}}$ & $11.96^{\mathrm{b}}$ & $11.68^{\mathrm{b}}$ & 0.165 & $* * *$ \\
\hline$\%$ IM fat & $0.81^{\mathrm{a}}$ & $1.77^{\mathrm{b}}$ & $1.85^{\mathrm{b}}$ & $2.39^{\mathrm{c}}$ & 0.068 & $* * *$ \\
\hline \multicolumn{7}{|c|}{$\begin{array}{l}\text { s.e.m.: standard error of the mean. }{ }^{* *}: P<0.001 ; \text { a,b,c,d Means with } \\
\text { different superscripts are significantly different at } P<0.05 \text {. } \\
\text { LWS: live weight at slaughter; CCW: cold carcass weight; IT: } \\
\text { intermuscular; SC: subcutaneous; total fat }(\%)=\mathrm{IT} \text { fat }(\%)+\mathrm{SC} \text { fat } \\
(\%) \text {; IM: intramuscular; AV: Asturiana de los Valles breed; AM: } \\
\text { Asturiana de la Montaña breed; } m h / m h \text { : double-muscled; } m h /+ \text { : } \\
\text { heterozygous; +/+: normal. }\end{array}$} \\
\hline
\end{tabular}


The dissection of the 6th rib as an estimation of the carcass composition of yearling bulls, showed that $\mathrm{mh} /$ $m h$ animals produced a significantly $(P<0.001)$ higher lean percentage $(84.4 \%)$ and lower total fat $(6.0 \%)$, due to lower IT $(4.9 \%)$ and SC $(1.1 \%)$ fat percentages. However, AM and $+/+$ animals showed the lowest lean (mean value of $75.4 \%$ ) and the highest total fat percentages (mean value of $12.7 \%$ ), whilst $\mathrm{mh} /+$ animals showed, in general, intermediate values (77.3\% and $11.0 \%$ for lean and total fat, respectively).
In all genotypes, IT fat was the greatest contributor to total fat at the dissection level. Double-muscled animals, having the highest muscular mass, showed the lowest bone percentage representing only $9.6 \%$ in comparison to the other genotypes (mean value of $11.8 \%$ ). According to linear regressions, total fat $(\mathrm{SC} \%+\mathrm{IT} \%)$ percentage of the rib dissection was negatively related to the carcass conformation score $(r=-0.68, P<0.001)$ and positively related to the fat cover degree $(r=0.60$, $P<0.001)$.

Table 3

Intramuscular individual fatty acid percentages ( $\%$ of total fatty acids quantified) of longissimus thoracis muscle for each genotype

\begin{tabular}{|c|c|c|c|c|c|c|c|c|}
\hline \multirow[t]{2}{*}{$\Sigma$ FA (mg/100 g meat) } & $\operatorname{AV}(m h / m h)$ & $\mathrm{AV}(m h /+)$ & $\mathrm{AV}(+/+)$ & $\mathrm{AM}$ & s.e.m. & Sign. & $\mathrm{C}$ & $\mathrm{FC}$ \\
\hline & $859.08^{\mathrm{a}}$ & $1790.65^{\mathrm{b}}$ & $1825.99^{\mathrm{b}}$ & $2355.00^{\mathrm{c}}$ & 68.222 & $* * *$ & $-0.67 * * *$ & $0.59 * * *$ \\
\hline \multicolumn{9}{|l|}{ FA (\%) } \\
\hline $\mathrm{C} 10: 0$ & $1.64 \mathrm{E}-02^{\mathrm{a}}$ & $2.58 \mathrm{E}-02^{\mathrm{b}}$ & $2.78 \mathrm{E}-02^{\mathrm{b}}$ & $3.82 \mathrm{E}-02^{\mathrm{c}}$ & 0.001 & $* * *$ & $-0.55^{* * *}$ & $0.34 * * *$ \\
\hline C12:0 & $4.39 \mathrm{E}-02^{\mathrm{a}}$ & $6.03 \mathrm{E}-02^{\mathrm{b}}$ & $6.56 \mathrm{E}-02^{\mathrm{b}}$ & $8.18 \mathrm{E}-02^{\mathrm{c}}$ & 0.002 & $* * *$ & $-0.56^{* * *}$ & $0.37 * * *$ \\
\hline C13:0 & $9.56 \mathrm{E}-03^{\mathrm{a}}$ & $1.11 \mathrm{E}-02^{\mathrm{a}, \mathrm{b}}$ & $1.24 \mathrm{E}-02^{\mathrm{b}, \mathrm{c}}$ & $1.30 \mathrm{E}-02^{\mathrm{c}}$ & 0.000 & $*$ & $-0.24^{*}$ & NS \\
\hline $\mathrm{C} 14: 0$ & $1.54^{\mathrm{a}}$ & $2.71^{\mathrm{b}}$ & $2.88^{\mathrm{b}}$ & $3.46^{\mathrm{c}}$ & 0.056 & $* * *$ & $-0.71 * * *$ & $0.64 * * *$ \\
\hline $\mathrm{C} 15: 0$ & $0.30^{\mathrm{a}}$ & $0.42^{\mathrm{b}}$ & $0.43^{\mathrm{b}}$ & $0.47^{\mathrm{c}}$ & 0.007 & $* * *$ & $-0.59 * * *$ & $0.52 * * *$ \\
\hline C16:0 & $24.25^{\mathrm{a}}$ & $28.62^{\mathrm{b}}$ & $28.89^{\mathrm{b}}$ & $30.85^{\mathrm{c}}$ & 0.206 & $* * *$ & $-0.72 * * *$ & $0.54 * * *$ \\
\hline $\mathrm{C} 17: 0$ & $0.85^{\mathrm{a}}$ & $1.12^{\mathrm{b}}$ & $1.12^{\mathrm{b}}$ & $1.09^{\mathrm{b}}$ & 0.014 & $* * *$ & $-0.43^{* * *}$ & $0.46^{* * *}$ \\
\hline C18:0 & 13.58 & 14.17 & 13.74 & 13.56 & 0.153 & NS & NS & NS \\
\hline C19:0 & $0.08^{\mathrm{a}}$ & $0.12^{\mathrm{b}}$ & $0.12^{\mathrm{b}}$ & $0.11^{\mathrm{b}}$ & 0.003 & $* * *$ & $-0.21^{*}$ & $0.37^{* * *}$ \\
\hline C20:0 & $9.68 \mathrm{E}-02^{\mathrm{b}}$ & $8.42 \mathrm{E}-02^{\mathrm{a}, \mathrm{b}}$ & $8.31 \mathrm{E}-02^{\mathrm{a}}$ & $8.15 \mathrm{E}-02^{\mathrm{a}}$ & 0.002 & NS & $0.23^{*}$ & $-0.27 * *$ \\
\hline $\mathrm{C} 22: 0$ & $1.85 \mathrm{E}-02^{\mathrm{b}}$ & $1.65 \mathrm{E}-02^{\mathrm{b}}$ & $1.50 \mathrm{E}-02^{\mathrm{a}, \mathrm{b}}$ & $1.05 \mathrm{E}-02^{\mathrm{a}}$ & 0.001 & $*$ & $0.29 * *$ & $-0.22 *$ \\
\hline isoC15:0 & $5.71 \mathrm{E}-02^{\mathrm{a}}$ & $7.59 \mathrm{E}-02^{\mathrm{b}}$ & $6.28 \mathrm{E}-02^{\mathrm{a}, \mathrm{b}}$ & $6.83 \mathrm{E}-02^{\mathrm{b}}$ & 0.002 & $* *$ & NS & NS \\
\hline anteisoC15:0 & $0.11^{\mathrm{a}}$ & $0.14^{\mathrm{b}}$ & $0.12^{\mathrm{a}}$ & $0.12^{\mathrm{a}}$ & 0.003 & $* * *$ & NS & NS \\
\hline isoC16:0 & $0.14^{\mathrm{b}}$ & $0.15^{\mathrm{b}}$ & $0.13^{\mathrm{a}, \mathrm{b}}$ & $0.13^{\mathrm{a}}$ & 0.003 & $* *$ & $0.24^{*}$ & NS \\
\hline iso $17: 0$ & $0.30^{\mathrm{c}}$ & $0.24^{\mathrm{b}}$ & $0.21^{\mathrm{a}}$ & $0.19^{\mathrm{a}}$ & 0.004 & $* * *$ & $0.58 * * *$ & $-0.56^{* * *}$ \\
\hline isoC18:0 & $5.92 \mathrm{E}-02^{\mathrm{b}}$ & $5.88 \mathrm{E}-02^{\mathrm{b}}$ & $6.00 \mathrm{E}-02^{\mathrm{b}}$ & $4.98 \mathrm{E}-02^{\mathrm{a}}$ & 0.001 & $*$ & $0.20^{*}$ & NS \\
\hline C14:1cis 9 & $0.18^{\mathrm{a}}$ & $0.32^{\mathrm{b}}$ & $0.41^{\mathrm{c}}$ & $0.45^{\mathrm{c}}$ & 0.013 & $* * *$ & $-0.55 * * *$ & $0.44 * * *$ \\
\hline C16:1cis9† & $1.51^{\mathrm{a}}$ & $2.47^{\mathrm{b}}$ & $2.38^{\mathrm{b}}$ & $2.81^{\mathrm{c}}$ & 0.045 & $* * *$ & $-0.71^{* * *}$ & $0.57 * * *$ \\
\hline $\mathrm{C} 17: 1 \operatorname{cis} 10$ & $0.39^{\mathrm{a}}$ & $0.56^{\mathrm{b}}$ & $0.64^{\mathrm{c}}$ & $0.65^{\mathrm{c}}$ & 0.011 & $* * *$ & $-0.60 * * *$ & $0.46^{* * *}$ \\
\hline C18:1trans & $5.74^{\mathrm{b}}$ & $5.33^{\mathrm{a}, \mathrm{b}}$ & $5.66^{\mathrm{b}}$ & $4.18^{\mathrm{a}}$ & 0.207 & $*$ & $0.25^{*}$ & NS \\
\hline $\mathrm{C} 18: 1$ cis 9 & $14.56^{\mathrm{a}}$ & $21.89^{\mathrm{b}}$ & $22.36^{\mathrm{b}, \mathrm{c}}$ & $23.90^{\mathrm{c}}$ & 0.305 & $* * *$ & $-0.74 * * *$ & $0.58^{* * *}$ \\
\hline C18:1cis 11 & $2.93^{\mathrm{a}, \mathrm{b}}$ & $3.08^{\mathrm{b}}$ & $2.97^{\mathrm{a}, \mathrm{b}}$ & $2.79^{\mathrm{a}}$ & 0.036 & $*$ & NS & NS \\
\hline $\mathrm{C} 18: 1$ cis 12 & $0.85^{\mathrm{a}}$ & $1.03^{\mathrm{b}}$ & $0.96^{\mathrm{b}}$ & $1.00^{\mathrm{b}}$ & 0.022 & $*$ & NS & $0.28 * *$ \\
\hline C18:1cis 13 & $0.23^{\mathrm{a}}$ & $0.30^{\mathrm{b}}$ & $0.33^{\mathrm{b}}$ & $0.31^{\mathrm{b}}$ & 0.006 & $* * *$ & $-0.41^{* * *}$ & $0.46^{* * *}$ \\
\hline$C 18: 2 n-6$ & $23.70^{\mathrm{c}}$ & $12.40^{\mathrm{b}}$ & $11.72^{\mathrm{a}, \mathrm{b}}$ & $9.86^{\mathrm{a}}$ & 0.440 & $* * *$ & $0.72 * * *$ & $-0.60 * * *$ \\
\hline C18:3n-6 & $0.38^{\mathrm{b}}$ & $0.14^{\mathrm{a}}$ & $0.19^{\mathrm{a}}$ & $0.14^{\mathrm{a}}$ & 0.010 & $* * *$ & $0.48^{* * *}$ & $-0.47 * * *$ \\
\hline C20:2n-6 & $0.19^{c}$ & $0.10^{\mathrm{a}, \mathrm{b}}$ & $0.12^{\mathrm{b}}$ & $0.08^{\mathrm{a}}$ & 0.004 & $* * *$ & $0.66^{* * *}$ & $-0.53^{* * *}$ \\
\hline$C 20: 3 n-6$ & $1.16^{\mathrm{b}}$ & $0.52^{\mathrm{a}}$ & $0.52^{\mathrm{a}}$ & $0.40^{\mathrm{a}}$ & 0.024 & $* * *$ & $0.70 * * *$ & $-0.61 * * *$ \\
\hline C20:4n-6 & $3.53^{\mathrm{b}}$ & $1.80^{\mathrm{a}}$ & $1.81^{\mathrm{a}}$ & $1.46^{\mathrm{a}}$ & 0.076 & $* * *$ & $0.67 * * *$ & $-0.58 * * *$ \\
\hline$C 22: 4 n-6$ & $0.49^{\mathrm{b}}$ & $0.27^{\mathrm{a}}$ & $0.26^{\mathrm{a}}$ & $0.24^{\mathrm{a}}$ & 0.011 & $* * *$ & $0.62^{* * *}$ & $-0.56^{* * *}$ \\
\hline C18:3n-3 & $0.96^{\mathrm{c}}$ & $0.79^{\mathrm{b}}$ & $0.75^{\mathrm{b}}$ & $0.66^{\mathrm{a}}$ & 0.011 & $* * *$ & $0.61 * * *$ & $-0.57 * * *$ \\
\hline C20:3n-3 & $8.02 \mathrm{E}-03^{\mathrm{b}}$ & $7.55 \mathrm{E}-03^{\mathrm{a}, \mathrm{b}}$ & $5.91 \mathrm{E}-03^{\mathrm{a}, \mathrm{b}}$ & $5.48 \mathrm{E}-03^{\mathrm{a}}$ & 0.000 & NS & NS & NS \\
\hline$C 20: 5 n-3$ & $0.47^{\mathrm{c}}$ & $0.23^{\mathrm{b}}$ & $0.22^{\mathrm{b}}$ & $0.14^{\mathrm{a}}$ & 0.011 & $* * *$ & $0.68 * * *$ & $-0.57 * * *$ \\
\hline$C 22: 5 n-3$ & $0.99^{c}$ & $0.47^{\mathrm{b}}$ & $0.48^{\mathrm{b}}$ & $0.35^{\mathrm{a}}$ & 0.020 & $* * *$ & $0.70^{* * *}$ & $-0.60^{* * *}$ \\
\hline$C 22: 6 n-3$ & $8.36 \mathrm{E}-02^{\mathrm{c}}$ & $3.60 \mathrm{E}-02^{\mathrm{b}}$ & $4.05 \mathrm{E}-02^{\mathrm{b}}$ & $2.15 \mathrm{E}-02^{\mathrm{a}}$ & 0.002 & $* * *$ & $0.71^{* * *}$ & $-0.55^{* * *}$ \\
\hline cis9,trans11-CLA & $0.16^{\mathrm{a}}$ & $0.23^{\mathrm{b}}$ & $0.19^{\mathrm{a}, \mathrm{b}}$ & $0.20^{\mathrm{a}, \mathrm{b}}$ & 0.008 & $*$ & $-0.20^{*}$ & $0.22 *$ \\
\hline trans 10 , cis $12-$ CLA & $3.06 \mathrm{E}-02^{\mathrm{b}}$ & $1.95 \mathrm{E}-02^{\mathrm{a}}$ & $2.33 \mathrm{E}-02^{\mathrm{a}, \mathrm{b}}$ & $2.12 \mathrm{E}-02^{\mathrm{a}}$ & 0.001 & $*$ & $0.22 *$ & NS \\
\hline
\end{tabular}

Correlation coefficients $(r)$ between carcass measurements (conformation and degree of fat cover) and fatty acids.

s.e.m.: standard error of the mean. ${ }^{*}: P<0.05 ;{ }^{* *}: P<0.01 ;{ }^{* * *}: P<0.001$; NS:P>0.05. ${ }^{\mathrm{a}, \mathrm{b}, \mathrm{c}}$ Means within a row with different superscripts are significantly different at $P<0.05$.

AV: Asturiana de los Valles breed; AM: Asturiana de la Montaña breed; $m h / m h$ : double-muscled; $m h /+$ : heterozygous; +/+: normal; C: conformation; FC: degree of fat cover; $\uparrow$ : coelution with anteisoC17:0; $\ddagger$ : coelution of several trans isomers; CLA=conjugated linoleic acid. 
The genotype or biological type affected significantly $(P<0.001)$ the IM fat content $(\%)$ of LT muscle where AM animals showed the highest fat content $(2.40 \%)$ and double-muscled animals the lowest $(0.81 \%)$, while the other genotypes $(\mathrm{mh} /+$ and $+/+)$ showed intermediate contents (mean value of $1.81 \%$ ).

\subsection{Muscle fatty acid profile}

Meat FA profile, expressed as \% of total FAs quantified $(\mathrm{g} / 100 \mathrm{~g}$ of total FAs) and organised as individuals in Table 3, and groups and ratios in Table 4, is presented for each genotype. In general, and for all genotypes, only four were the FAs which showed larger proportions than $10 \%(\mathrm{C} 16: 0, \mathrm{C} 18: 0, \mathrm{C} 18: 1$ cis $9, \mathrm{C} 18: 2 \mathrm{n}-$ 6) which represented around $77 \%$ of the total FAs. Another six were the FAs which showed proportions between $1 \%$ and $10 \%$ (C14:0, C17:0, C16:1cis9, C18:1trans, C18:1cis11, C20:4n-6) and represented $16 \%$ of the total FAs. The rest of the FAs were considered minor FAs as they represented individually lower proportions than $1 \%$ of the total FAs.

Significant $(P<0.05)$ differences due to the genotype were observed in $89 \%$ of the individual (major and minor) FAs (Table 3). Considered FA groups (SFA, BFA, MUFA, PUFA, n-6, n-3, UFA) and ratios (M/S, P/ $\mathrm{S}, \mathrm{U} / \mathrm{S}, \mathrm{n}-6 / \mathrm{n}-3)$ showed significant $(P<0.001)$ differences due to the genotype effect, except for CLA group (Table 4). Generally, double-muscled animals showed the lowest individual and total SFA percentages (40.8\%), while AM animals had the highest values (49.8\%). The other two genotypes $(m h /+,+/+)$ showed intermediate levels (mean value of $47.4 \%$ ). However, no significant differences between biological types were found for C18:0, being this one of the major FA.

Significant differences were found between genotypes for BFA individuals and group, where they seemed to be higher in leaner animals, except for iso 1 15:0, showing an opposite trend, and anteiso C15:0, not showing any clear trend.

In double-muscled animals, total MUFA percentage was significantly $(P<0.001)$ lower $(26.4 \%)$ than in the other genotypes (mean value of $35.6 \%$ ). When comparing MUFAs individually, double-muscled animals showed, in general, lower percentages in FAs with less than 18 carbon atoms. Normal and AM animals presented the highest percentages, while $m h /+$ animals showed intermediate values. The $\mathrm{C} 16: 1$ cis 9 and anteisoC17:0 were reported together as we could not separate them probably because of the higher proportion of C16:1 cis 9 in comparison to anteiso $\mathrm{C} 17: 0$ in beef muscle fat. Similar trend was observed for FAs composed by 18 carbon atoms where double muscled animals showed the lowest percentages in comparison to other biological types which had similar values. However, opposite effect was found for C18:1trans (trans group value was reported as this column incompletely resolved them, and we could not exclude some minor contamination

Table 4

Intramuscular fatty acid group percentages (\% of total fatty acids quantified) and ratios of longissimus thoracis muscle for each genotype

\begin{tabular}{|c|c|c|c|c|c|c|c|c|}
\hline & $\mathrm{AV}(m h / m h)$ & $\operatorname{AV}(m h /+)$ & $\mathrm{AV}(+/+)$ & AM & s.e.m. & Sign. & $\mathrm{C}$ & $\mathrm{FC}$ \\
\hline SFA & $40.79^{\mathrm{a}}$ & $47.35^{\mathrm{b}}$ & $47.38^{\mathrm{b}}$ & $49.76^{\mathrm{c}}$ & 0.310 & $* * *$ & $-0.69 * * *$ & $0.53 * * *$ \\
\hline BFA & $0.67^{\mathrm{b}}$ & $0.66^{\mathrm{b}}$ & $0.58^{\mathrm{a}}$ & $0.56^{\mathrm{a}}$ & 0.009 & $* * *$ & $0.33 * * *$ & $-0.28 * *$ \\
\hline MUFA & $26.39^{\mathrm{a}}$ & $34.98^{\mathrm{b}}$ & $35.71^{\mathrm{b}}$ & $36.10^{\mathrm{b}}$ & 0.339 & $* * *$ & $-0.69 * * *$ & $0.62 * * *$ \\
\hline PUFA & $32.16^{\mathrm{c}}$ & $17.01^{\mathrm{b}}$ & $16.33^{\mathrm{ab}}$ & $13.58^{\mathrm{a}}$ & 0.579 & $* * *$ & $0.72 * * *$ & $-0.61 * * *$ \\
\hline$n-6$ & $29.45^{\mathrm{b}}$ & $15.24^{\mathrm{a}}$ & $14.62^{\mathrm{a}}$ & $12.18^{\mathrm{a}}$ & 0.549 & $* * *$ & $0.72^{* * *}$ & $-0.60 * * *$ \\
\hline$n-3$ & $2.51^{\mathrm{c}}$ & $1.53^{\mathrm{b}}$ & $1.49^{\mathrm{b}}$ & $1.18^{\mathrm{a}}$ & 0.040 & $* * *$ & $0.71 * * *$ & $-0.62 * * *$ \\
\hline UFA & $58.54^{\mathrm{c}}$ & $51.99^{\mathrm{b}}$ & $52.04^{\mathrm{b}}$ & $49.68^{\mathrm{a}}$ & 0.310 & $* * *$ & $0.69 * * *$ & $-0.53 * * *$ \\
\hline CLA & 0.20 & 0.25 & 0.21 & 0.22 & 0.008 & NS & NS & NS \\
\hline $\mathrm{M} / \mathrm{S}$ & $0.65^{\mathrm{a}}$ & $0.74^{\mathrm{b}}$ & $0.75^{\mathrm{b}}$ & $0.72^{\mathrm{b}}$ & 0.006 & $* * *$ & $-0.44 * * *$ & $0.48 * * *$ \\
\hline $\mathrm{P} / \mathrm{S}$ & $0.81^{\mathrm{b}}$ & $0.36^{\mathrm{a}}$ & $0.35^{\mathrm{a}}$ & $0.28^{\mathrm{a}}$ & 0.018 & $* * *$ & $0.70 * * *$ & $-0.58 * * *$ \\
\hline $\mathrm{U} / \mathrm{S}$ & $1.46^{\mathrm{c}}$ & $1.10^{\mathrm{b}}$ & $1.11^{\mathrm{b}}$ & $1.00^{\mathrm{a}}$ & 0.017 & $* * *$ & $0.67^{* * *}$ & $-0.52 * * *$ \\
\hline$n-6 / n-3$ & $11.79^{\mathrm{b}}$ & $10.05^{\mathrm{a}}$ & $9.68^{\mathrm{a}}$ & $10.17^{\mathrm{a}}$ & 0.190 & $* * *$ & $0.34 * * *$ & $-0.30 * *$ \\
\hline
\end{tabular}

Correlation coefficients $(r)$ between carcass measurements (conformation and degree of fat cover) and FAs groups and ratios.

s.e.m.: standard error of the mean. ${ }^{* *}: P<0.01 ;{ }^{* *}: P<0.001$; NS:P>0.05. ${ }^{\mathrm{a}, \mathrm{b}, \mathrm{c}}$ Means within a row with different superscripts are significantly different at $P<0.05$.

$\mathrm{SFA}=\mathrm{C} 10: 0+\mathrm{C} 12: 0+\mathrm{C} 13: 0+\mathrm{C} 14: 0+\mathrm{C} 15: 0+\mathrm{C} 16: 0+\mathrm{C} 17: 0+\mathrm{C} 18: 0+\mathrm{C} 19: 0+\mathrm{C} 20: 0+\mathrm{C} 22: 0 ; \quad \mathrm{BFA}=$ iso $15: 0+$ anteiso $15: 0+i s o \mathrm{C} 16: 0+$ iso $\mathrm{C} 17: 0+$ iso $\mathrm{C} 18: 0 ; \quad \mathrm{MUFA}=\mathrm{C} 14: 1$ cis $9+\mathrm{C} 16: 1$ cis $9+\mathrm{C} 17: 1$ cis $10+\mathrm{C} 18: 1$ trans $+\mathrm{C} 18: 1$ cis $9+\mathrm{C} 18: 1$ cis $11+\mathrm{C} 18: 1$ cis $12+\mathrm{C} 18: 1$ cis 13 ; PUFA $=C 18: 2 n-6+C 18: 3 n-6+C 20: 2 n-6+C 20: 3 n-6+C 20: 4 n-6+C 22: 4 n-6+C 18: 3 n-3+C 20: 3 n-3+C 20: 5 n-3+C 22: 5 n-3+C 22: 6 n-3+$ cis 9 , trans $11-$ $\mathrm{CLA}+$ trans 10, cis 12-CLA; n- $6=\mathrm{C} 18: 2 \mathrm{n}-6+\mathrm{C} 18: 3 \mathrm{n}-6+\mathrm{C} 20: 2 \mathrm{n}-6+\mathrm{C} 20: 3 \mathrm{n}-6+\mathrm{C} 20: 4 \mathrm{n}-6+\mathrm{C} 22: 4 \mathrm{n}-6 ; \mathrm{n}-3=\mathrm{C} 18: 3 \mathrm{n}-3+\mathrm{C} 20: 3 \mathrm{n}-3+\mathrm{C} 20: 5 \mathrm{n}-3+$ C22:5n-3+C22:6n-3; UFA = MUFA + PUFA; CLA=cis9,trans11-CLA+trans10, cis12-CLA; CLA = conjugated linoleic acid; M/S=MUFA/SFA; $\mathrm{P} / \mathrm{S}=\mathrm{PUFA} / \mathrm{SFA} ; \mathrm{U} / \mathrm{S}=\mathrm{UFA} / \mathrm{SFA} ; \mathrm{AV}$ : Asturiana de los Valles breed; AM: Asturiana de la Montaña breed; $m h / m h$ : double-muscled; $m h /+$ : heterozygous; +/+: normal; C: conformation; FC: degree of fat cover. 
with other C18:1trans isomers) where its content in meat of AM animals was significantly lower than in other genotypes except for $\mathrm{mh} /+$ group.

Concerning total PUFA, n-3 and UFA percentages similar trend was observed. Double-muscled animals presented the highest values $(32.2 \%, 2.5 \%, 58.5 \%)$ and AM animals the lowest $(13.6 \%, 1.2 \%, 49.7 \%)$, while the other genotypes $(\mathrm{mh} /+,+/+)$ showed intermediate contents (mean values of $16.7 \%, 1.5 \%$ and $52 \%$ for PUFA, n-3 and UFA, respectively). When the n- 6 group was analysed, the highest percentage was observed in double-muscled animals (29.4\%) while lower values were found in the other genotypes (mean value of $14.0 \%$ ). Individually, n-3 and n-6 type of FAs, showed similar tendency to their main groups, but have been observed some exceptions.

The cis9,trans 11 and trans 10 ,cis 12 were the reported CLA isomers. Significant $(P<0.05)$ differences were found between genotypes and double-muscled animals presented the lowest cis9, trans11-CLA and the highest trans10,cis12-CLA percentages in comparison to the other three genotypes (Table 3 ).

Referring to FA group ratios, similar and high $\mathrm{M} / \mathrm{S}$ values (mean value of 0.74 ) were observed in $\mathrm{mh} /+,+$ / + and AM animals while double-muscled animals had lower values (0.65). Opposite effect was found for $\mathrm{P} / \mathrm{S}$ and $n-6 / n-3$ ratios where double-muscled animals showed the highest values $(0.81$ and 11.8 for $\mathrm{P} / \mathrm{S}$ and $\mathrm{n}-6 / \mathrm{n}-3$, respectively) while in the other three genotypes lower values (mean values of 0.33 and 10.0 for $\mathrm{P} / \mathrm{S}$ and $\mathrm{n}-6 / \mathrm{n}-3$, respectively) were observed. For U/S ratio, the highest ratio happened in double-muscled animals (1.5) and the lowest in AM animals (1.0), while intermediate values were found in the other two genotypes (mean value of 1.1) (Table 4).

\subsubsection{Relationship between carcass measurements and muscle fatty acid profile}

Since independent genotypes did not show any significant relationship between carcass measurements and FAs (individuals, groups, ratios), all genotypes were grouped and analysed together. Correlation analysis between carcass rapid measurements (conformation and degree of fat cover) and meat FA profile are summarised in Tables 3 and 4.

IM fat content (\%) (Table 2) was negatively related to the carcass conformation $(r=-0.65, P<0.001)$ while positively to the degree of fat cover $(r=0.60, P<0.001)$. Between carcass conformation score and SFA $(r=$ $-0.69)$ and MUFA $(r=-0.69)$ groups negative $(P<0.001)$ correlations were found. And, in general, the same trend was observed for individual FAs of these groups with some exceptions. C18:0 was one the major FA which showed no correlation with conformation score. On the other hand, positive correlations $(P<0.001)$ were found between carcass conformation scores and PUFA $(r=0.72), \mathrm{n}-6(r=0.72), \mathrm{n}-3 \quad(r=0.71)$ and UFA $(r=0.69)$ groups. In general, similar trend was observed for individual FAs of the same groups, except for $\mathrm{C} 20: 3 n-3$ which had no correlation with conformation score. Moreover, CLA isomers showed low correlations (negative for cis9, trans 11-CLA and positive for trans10,cis12-CLA isomer). According to FA group ratios, positive $(P<0.001)$ correlations were found between conformation scores and $\mathrm{P} / \mathrm{S}(r=0.70)$ and $\mathrm{U} /$ $\mathrm{S}(r=0.67)$.

Referring to carcass degree of fat cover, positive correlations $(P<0.001)$ were observed between this score and SFA $(r=0.53)$ and MUFA $(r=0.62)$ groups. In general, the same tendency was observed for individual SFA with some exceptions. Again, C18:0 was one of the

Table 5

Estimated linear regression equations

\begin{tabular}{|c|c|c|c|}
\hline Equation & $R^{2}$ & Sign. & s.e. \\
\hline $\operatorname{SFA}(\%)=-1.19_{(0.13)} \mathrm{C}+58.88_{(1.36)}$ & 0.479 & $* * *$ & 3.23 \\
\hline $\mathrm{BFA}(\%)=0.01_{(0.004)} \mathrm{C}+0.47_{(0.05)}$ & 0.107 & $* * *$ & 0.11 \\
\hline $\operatorname{MUFA}(\%)=-0.97_{(0.18)} \mathrm{C}+0.90_{(0.26)} \mathrm{FC}+39.76_{(2.70)}$ & 0.535 & $* * *$ & 3.53 \\
\hline PUFA $(\%)=1.98_{(0.30)} \mathrm{C}-1.30_{(0.44)} \mathrm{FC}+4.43_{(4.64)}$ & 0.564 & $* * *$ & 6.06 \\
\hline $\mathrm{n}-6(\%)=1.85_{(0.28)} \mathrm{C}-1.21_{(0.42)} \mathrm{FC}+3.50_{(4.40)}$ & 0.556 & $* * *$ & 5.75 \\
\hline $\mathrm{n}-3(\%)=0.13_{(0.02)} \mathrm{C}-0.10_{(0.03)} \mathrm{FC}+0.72_{(0.33)}$ & 0.552 & $* * *$ & 0.43 \\
\hline $\operatorname{UFA}(\%)=1.17_{(0.13)} \mathrm{C}+40.66_{(1.36)}$ & 0.470 & $* * *$ & 3.25 \\
\hline
\end{tabular}

$R^{2}$ : coefficient of determination; s.e.: standard error of the estimate; values in parentheses are standard errors of the coefficients; $* * *: P<0.001$. $\mathrm{SFA}=\mathrm{C} 10: 0+\mathrm{C} 12: 0+\mathrm{C} 13: 0+\mathrm{C} 14: 0+\mathrm{C} 15: 0+\mathrm{C} 16: 0+\mathrm{C} 17: 0+\mathrm{C} 18: 0+\mathrm{C} 19: 0+\mathrm{C} 20: 0+\mathrm{C} 22: 0 ; \mathrm{BFA}=i s o \mathrm{C} 15: 0+$ anteisoC $15: 0+i s o \mathrm{C} 16: 0+i s o \mathrm{C} 17: 0+$ iso $\mathrm{C} 18: 0 ; \mathrm{MUFA}=\mathrm{C} 14: 1$ cis $9+\mathrm{C} 16: 1$ cis $9+\mathrm{C} 17: 1$ cis $10+\mathrm{C} 18: 1$ trans $+\mathrm{C} 18: 1$ cis $9+\mathrm{C} 18: 1$ cis $11+\mathrm{C} 18: 1$ cis $12+\mathrm{C} 18: 1$ cis $13 ; \mathrm{PUFA}=\mathrm{C} 18: 2 \mathrm{n}-6+\mathrm{C} 18: 3 \mathrm{n}-6+$ $\mathrm{C} 20: 2 \mathrm{n}-6+\mathrm{C} 20: 3 \mathrm{n}-6+\mathrm{C} 20: 4 \mathrm{n}-6+\mathrm{C} 22: 4 \mathrm{n}-6+\mathrm{C} 18: 3 \mathrm{n}-3+\mathrm{C} 20: 3 \mathrm{n}-3+\mathrm{C} 20: 5 \mathrm{n}-3+\mathrm{C} 22: 5 \mathrm{n}-3+\mathrm{C} 22: 6 \mathrm{n}-3+$ cis 9 , trans $11-\mathrm{CLA}+$ trans 10 , cis $12-\mathrm{CLA} ; \mathrm{n}-$ $6=\mathrm{C} 18: 2 n-6+\mathrm{C} 18: 3 n-6+\mathrm{C} 20: 2 n-6+C 20: 3 n-6+C 20: 4 n-6+C 22: 4 n-6 ; n-3=C 18: 3 n-3+C 20: 3 n-3+C 20: 5 n-3+C 22: 5 n-3+C 22: 6 n-3$; UFA $=$ MUFA + PUFA; : conformation;FC: degree offatcover. 


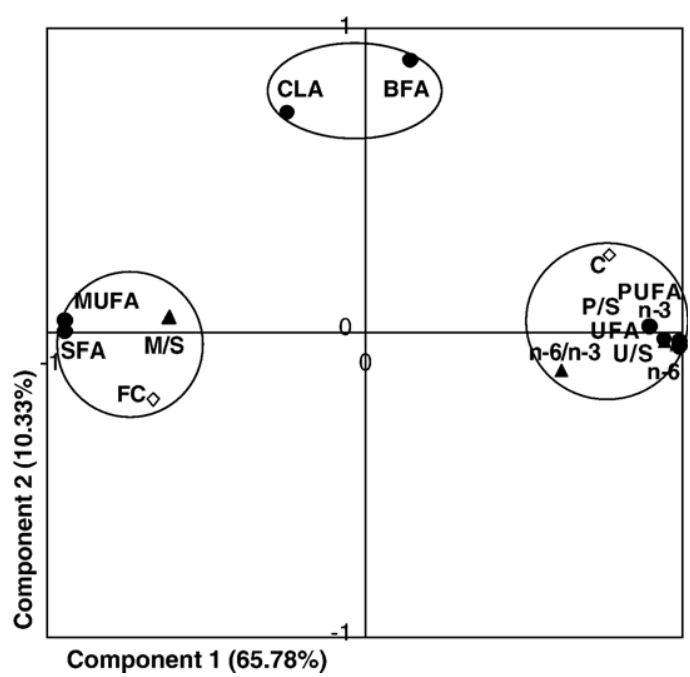

Fig. 1. Loading plot of the variables (fatty acid groups and ratios, and carcass measurement scores) included in the Principal Component Analysis. SFA $=\mathrm{C} 10: 0+\mathrm{C} 12: 0+\mathrm{C} 13: 0+\mathrm{C} 14: 0+\mathrm{C} 15: 0+\mathrm{C} 16: 0+$ $\mathrm{C} 17: 0+\mathrm{C} 18: 0+\mathrm{C} 19: 0+\mathrm{C} 20: 0+\mathrm{C} 22: 0 ; \quad \mathrm{BFA}=i s o \mathrm{C} 15: 0+$ antei soC $15: 0+i s o \mathrm{C} 16: 0+i s o \mathrm{C} 17: 0+i s o \mathrm{C} 18: 0 ; \quad \mathrm{MUFA}=\mathrm{C} 14: 1$ cis $9+$ $\mathrm{C} 16: 1$ cis $9+\mathrm{C} 17: 1$ cis $10+\mathrm{C} 18: 1$ trans $+\mathrm{C} 18: 1$ cis $9+\mathrm{C} 18: 1$ cis $11+$ $\mathrm{C} 18: 1$ cis $12+\mathrm{C} 18: 1$ cis $13 ; \quad \mathrm{PUFA}=\mathrm{C} 18: 2 \mathrm{n}-6+\mathrm{C} 18: 3 \mathrm{n}-6+\mathrm{C} 20: 2 \mathrm{n}-6+$ $\mathrm{C} 20: 3 \mathrm{n}-6+\mathrm{C} 20: 4 \mathrm{n}-6+\mathrm{C} 22: 4 \mathrm{n}-6+\mathrm{C} 18: 3 \mathrm{n}-3+\mathrm{C} 20: 3 \mathrm{n}-3+\mathrm{C} 20: 5 \mathrm{n}-3+$ C22:5n-3 + C22:6n-3 + cis9, trans11-CLA + trans 10, cis12-CLA; n$6=\mathrm{C} 18: 2 \mathrm{n}-6+\mathrm{C} 18: 3 \mathrm{n}-6+\mathrm{C} 20: 2 \mathrm{n}-6+\mathrm{C} 20: 3 \mathrm{n}-6+\mathrm{C} 20: 4 \mathrm{n}-6+\mathrm{C} 22: 4 \mathrm{n}-$ $6 ; n-3=C 18: 3 n-3+C 20: 3 n-3+C 20: 5 n-3+C 22: 5 n-3+C 22: 6 n-3$; $\mathrm{UFA}=\mathrm{MUFA}+\mathrm{PUFA} ; \mathrm{CLA}=$ cis 9 , trans $11-\mathrm{CLA}+\operatorname{trans} 10$, cis $12-$ CLA; CLA = conjugated linoleic acid; M/S=MUFA/SFA; P/ $\mathrm{S}=\mathrm{PUFA} / \mathrm{SFA} ; \mathrm{U} / \mathrm{S}=\mathrm{UFA} / \mathrm{SFA}$; $\mathrm{C}$ : conformation; FC: degree of fat cover.

major FA which showed no correlation, while $\mathrm{C} 16: 0$ and C14:0 were the FAs which mainly followed the observed correlation. In MUFA group, on the other hand, C16:1cis9 and C18:1cis9 were the FAs which mainly influenced the observed correlation. However, negative correlations $(P<0.001)$ were found between fat cover score and PUFA $(r=-0.61), \mathrm{n}-6(r=-0.60), \mathrm{n}-3$ $(r=-0.62)$ and UFA $(r=-0.53)$ groups. In general, the same trend was observed for individual FAs except for C20:3n-3, which again did not show any correlation, and CLA isomers where cis9, trans 11 isomer showed a low but positive correlation while trans 10 , cis 12 had no correlation. According to FA group ratios, negative $(P<0.001)$ correlation was found between fat cover degree score and $\mathrm{P} / \mathrm{S}(r=-0.58)$ and $\mathrm{U} / \mathrm{S}(r=-0.52)$. Neither carcass conformation nor fat cover degree scores showed strong correlations with BFA (individuals or group) except for isoC17:0 ( $r=0.58$ for conformation and $r=-0.56$ for fat cover degree scores, $P<0.001)$.

Trying to predict muscle FA group proportions, linear equations were estimated from carcass conformation and fat cover degree scores (predictor variables) (Table 5). Simple regression equations $(P<0.001)$, with conformation score as an independent variable, were obtained to predict SFA $\left(R^{2}=0.48\right)$ and UFA $\left(R^{2}=0.69\right)$ proportions. While multiple regression equations $(P<0.001)$, with carcass conformation and fat cover degree scores as independent variables, were obtained to predict MUFA $\left(R^{2}=0.54\right)$, PUFA $\left(R^{2}=0.56\right), \mathrm{n}-6\left(R^{2}=0.56\right)$ and $\mathrm{n}-3$ $\left(R^{2}=0.55\right)$ contents. In this sense, although conformation and fat cover degree scores were significantly correlated, multiple regressions, including both variables, improved the prediction of MUFA, PUFA, n- 6 and n-3 groups. In contrast, equation with very poor coefficient of determination was obtained for BFA, and no significant regression was found for CLA proportion. To ensure the prediction capacity of the estimated equations (Table 5) cross validation of them was carried out. From the total amount of samples in this study $(N=100)$, a sub-sample $(n=80)$ was taken at random and new prediction equations were calculated for each FA group (SFA, BFA, MUFA, PUFA, n-6, n-3, UFA). Then, with the rest of the samples not included in the prediction step $(n=20)$ obtained equations were checked. The outlined procedure was repeated twice and, in general, the percentage of accuracy obtained was of $75 \%$ or higher for all FA groups in both repetitions. According to this verification, the estimated equations from carcass conformation and fat cover degree scores could be useful to predict main muscle FA group contents (\%).

\subsection{Principal component analysis}

Principal Component Analysis (PCA) was carried out including carcass measurements (conformation and fat

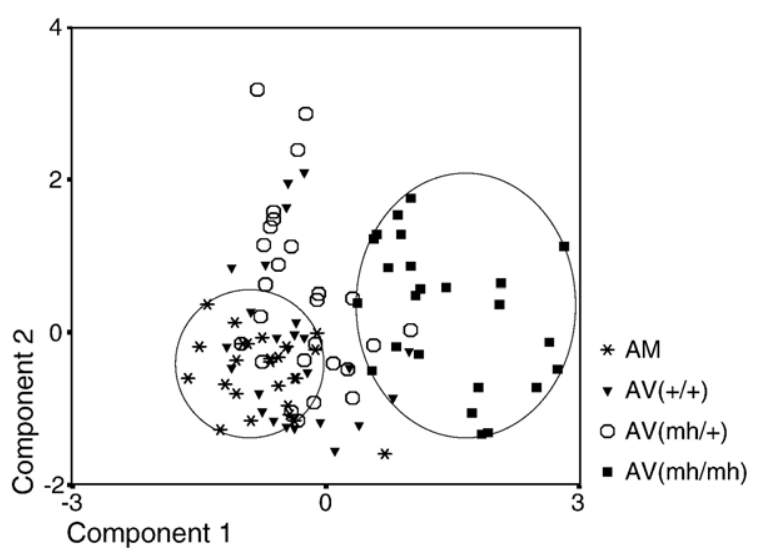

Fig. 2. Plot of the samples analysed in function of the obtained data from Principal Component Analysis. AV: Asturiana de los Valles; AM: Asturiana de la Montaña; $\mathrm{mh} / \mathrm{mh}$ : double-muscled; $\mathrm{mh} /+$ : heterozygous; +/+: normal. 
cover degree scores) and FA groups and ratios as study variables. There were obtained three principal components which explained the $84.16 \%$ of the variability found among samples. Fig. 1 shows the loading plot, using the first two components, where aforementioned variables are represented. Component 1 explained the $65.78 \%$ of the variability and it was positively defined by polyunsaturated groups and ratios (PUFA, UFA, n-6, n$3, \mathrm{P} / \mathrm{S}, \mathrm{U} / \mathrm{S}, \mathrm{n}-6 / \mathrm{n}-3$ ) and carcass conformation score, but negatively defined by more saturated groups and ratios (SFA, MUFA, M/S) and carcass fat cover degree score. Component 2 explained the $10.33 \%$ of the variance, showing high values for minor and rumenic FAs (CLA, BFA). In Fig. 2, sample representation on the first two components obtained in the PCA is shown, and thus, the reliability of using muscle FA profile and carcass measurement scores to allocate genotypes (or different samples). Double-muscled animals were quite well separated from the rest of the genotypes and thus related to highly unsaturated FAs (groups and ratios) and to conformation score. However, high dispersion was observed for this group. In contrary, AM animals appeared forming an homogeneous group and they were mainly related to SFA, MUFA, M/S and fat cover degree score as it was previously seen in correlation data. Normal animals tended to locate near AM, having a quite similar FA profile, while $\mathrm{mh} /+$ or heterozygous animals were characterised by high dispersion due to the high heterogeneity within this group, and they were located in the intermediate area between AM and $m h / m h$ genotypes.

\section{Discussion}

Animal growth performance, according to a lower live weight gains, was inferior in AM animals in comparison to the other genotypes studied, probably due to the rusticity of these animals, and this was also reflected in lower live and carcass weights. Moreover, AM animals obtained the lowest conformation and the highest fat cover degree scores in agreement with earlier studies comparing AV and AM breeds (Martínez et al., 2003) and with other Spanish and European breeds (Piedrafita et al., 2003). Double-muscled cattle are, in general, characterised by a better feed conversion and higher energetic efficiency of protein deposition and less efficient fat deposition compared to other animal groups as was found by Demeyer et al. (1995). Consequently, double muscling character produced a significant increase in carcass conformation, and a significant decrease in fat cover scores and fineness of bones as widely reported in Belgian Blue (Bouton et al., 1982;
Uytterhaegen et al., 1994; Arthur, 1995; Nürnberg et al., 1999), Piedmontese (Wheeler et al., 2001; Biagini and Lazzaroni, 2005) and AV breeds (Martínez et al., 2003; Oliván et al., 2004). As reported in earlier studies (Martínez et al., 2003; Aldai et al., 2006a), the lower fat cover degree of $\mathrm{mh} / \mathrm{mh}$ animals was also reflected in the dissection of the 6th rib which showed significantly higher lean and lower total, IT and SC fat proportions. Moreover, they presented the lowest IM fat proportion in comparison to the other genotypes $(\mathrm{mh} /+,+/+, \mathrm{AM})$ probably caused by the reduced production of adipocytes and the reduced fat cell diameter as found by Nürnberg et al. (1999) in Belgian Blue animals. Whilst a completely opposite pattern was followed by AM breed, being these the fattiest animals.

According to previous works (Eichhorn et al., 1985; Nürnberg et al., 1999), breed affects the composition of fat tissue mainly through its effect on total fat content. In this sense, the lowest percentages of SFA and MUFA, and the highest proportions of PUFA and UFA were observed in meat from the leanest animals $(\mathrm{mh} / \mathrm{mh})$, and the opposite effect was found in the fattest animals (AM) corresponding with previous works with animals fed on just concentrate (Nürnberg et al., 1999; Raes et al., 2001; Aldai et al., 2006a) or a high concentrate ration (Purchas et al., 2005). On the other hand, $\mathrm{mh} /+$ and $+/+$ animals, having an intermediate IM fat content, showed medium SFA, PUFA and UFA percentages but high proportion of MUFA as happened in the fattiest animals (AM). The higher IM fat content of yearling bulls of AM breed compared to $\mathrm{mh} / \mathrm{mh}$ was mainly due to a higher absolute contents of SFA and MUFA, while the absolute PUFA content was constant through all the genotypes (mean value of $273 \mathrm{mg} / 100 \mathrm{~g}$ muscle, $P>0.05$ ). These variations on the major FA groups could be related to the heterogeneous composition of IM fat, containing mainly triglycerides in adipocytes (between bundles of fibres) and muscular cells (as lipid droplets), and polar lipids, mainly phospholipids, in the membrane structures of both cell types where lower fat content reflects fewer and smaller adipocytes, containing fewer triglycerides, accompanied by a relative increase in the proportion of phospholipids and an increased PUFA content (Nürnberg et al., 1999; Laborde et al., 2001; Raes et al., 2003). Differences observed in FA groups of lean and fatty animals were fairly well reflected in the correlations carried out with carcass measurement scores (Tables 3 and 4). In general, the conformation score obtained better correlations with muscle FAs than the fat cover degree score did. Carcass measurements are related to animal muscle development, and in general, muscle development is negatively related to animal fatness and thus, to 
fat cover degree score (Piedrafita et al., 2003). In this sense, the better muscle development and carcass conformation were, the lower fat content was, being also reflected in the muscle FA composition (Raes et al., 2003; De Smet et al., 2004). Animal carcass conformation was positively correlated with unsaturated groups (PUFA, n-6, n-3, UFA), and negatively with SFA and MUFA as reported by Clinquart et al. (1991, 1994). While degree of fat cover showed positive correlations with SFA and MUFA, and negative correlations with unsaturated groups (PUFA, n-6, n-3, UFA), also found by Lo Fiego et al. (2005) in pigs from different genotypes and Kosulwat et al. (2003) in lambs from different carcass classification scores.

For many years, reducing carcass fatness has been one of the major breeding goals in beef cattle. Fat deposition is highly heritable and, depending on the emphasis that is put on this trait relative to other selection traits, breeds and animals within breeds may strongly differ in their mean carcass and meat fat content (Marschall, 1999). In AV breed, double-muscled gene is an heritable major gene which correlates negatively with carcass fatness and IM fat content, and positively with meat yield. In contrast, differences in maturity, age and/or live weight at slaughter contribute to differences in fatness, whereas AM breed being an early-maturing and rustic biological type have low meat yield but high IM fat content. Due to the high phenotypical heterogeneity, $m h /+$ animals were distributed between lean and fatty genotypes.

Concerning n-6 and n-3 FAs, these appeared in significantly higher proportions in double-muscled animal tissue than in the other genotypes, and they were positively correlated with carcass conformation and negatively with fat cover degree scores as was observed by Kosulwat et al. (2003) between fatness score and FA profile in lamb, and by Lo Fiego et al. (2005) between backfat thickness and FA profile in pork.

The major FA of n-6 group, C18:2n-6 percentage, was significantly $(P<0.001)$ higher in double-muscled animals $(23.7 \%)$ than in AM animals $(9.9 \%)$, while the other two genotypes $(\mathrm{mh} /+,+/+)$ showed intermediate percentages (mean value of $12.1 \%$ ). On the other hand, no significant differences between genotypes were found when comparing absolute contents (mean value of $198.3 \mathrm{mg} / 100 \mathrm{~g}$ muscle, $P>0.05)$. In this sense, the high percentage of C18:2n-6 found in animals with double muscling character in comparison to the other genotypes seemed to be related to the lower total IM fat content. The low proportions of this FA were also found in other studies carried out with intensively fed Belgian Blue (Raes et al., 2001) and German Simmental
(Nürnberg et al., 2005) bulls of 600-650 kg live weight at slaughter.

Referring to minor FA groups of muscle tissue, BFAs, which are of microbial origin (predominantly bacterial), made up an average value of $0.62 \%$ in IM fat. Similar values were obtained by Rule et al. (2002) in concentrate fed beef cattle and Wolff (1995) and Leth et al. (1998) in different retail cuts. Nevertheless, Duncan and Garton (1978) and Bas and Morand-Fehr (2000) found that BFAs of bacterial origin could make up from 1 to $3 \%$ of carcass lipids in ruminants. Oddchain and BFA in meat and milk have been considered tools for characterising rumen bacterial populations while these are influenced by feeding strategies (Dewhurst et al., 2002; Vlaeminck et al., 2002). In this study, concentrate meal was equal for all animals within the experimental design, what makes probable that differences in BFA percentages between animal groups could be related to the genotype and, consequently, to the total muscle fat content. However, poor relationships were found between carcass measurements and these FAs (BFA) decreasing their predictability using carcass scores measured at abattoir level.

The average value of total CLA percentage found in muscle fat was $0.22 \%$. The reported isomers were cis 9 , trans 11 and trans 10, cis 12 as these are considered the major isomers in ruminant products (Dehority, 2003). Content of trans10,cis12-CLA was much lower than cis9,trans11-CLA in muscle tissue examined as found in other studies (Chin et al., 1992; Mossoba et al., 1999). Double-muscled animals showed the lowest cis9, trans11-CLA percentage in comparison to the other genotypes, probably because its content was positively related to the fat content, and hence with variation in the neutral lipid fraction (Kazala et al., 1999; Raes et al., 2001). Moreover, in animal tissues, it is known that cis9, trans11-CLA isomer can be also synthesised endogenously from C18:1trans 11 . The enzyme responsible for the conversion of C18:1trans 11 into cis 9 , trans11-CLA is $\Delta$ 9-desaturase (Chang et al., 1992; Palmquist and Santora, 1999; Griinari et al., 2000; Corl et al., 2001) and its activity can be enhanced or inhibited depending on breed or genotype. The higher fat content and the possible higher desaturase activity in fatty animals, as found by Siebert et al. (2003), could help to explain the higher cis9,trans11-CLA content in these animals in comparison to lean animals. However, the general low content of $c i s 9$, $\operatorname{tran} 11-C L A$ in muscle tissue (half of that observed by other authors (Nürnberg et al., 2002; Rule et al., 2002)) with the employment of concentrate fairly rich in linoleic acid $(\mathrm{C} 18: 2 \mathrm{n}-6)$ in the current study (Table 1) could have been due to the low 
production of $\mathrm{C} 18: 1$ trans 11 in the rumen and/or decreased activity of $\Delta 9$-desaturase (Hristov et al., 2005). In contrast with our previous work with a lower number of animals (Aldai et al., 2006a), in the present work we have found a linear correlation between C18:1trans and cis9, trans11-CLA in absolute basis $(\mathrm{mg} / 100 \mathrm{~g}$ of muscle) $(r=0.46, P<0.001)$ as seen in some other studies (Enser et al., 1999; Lawless et al., 1999). Probably the influence of trans isomers other than C18:1trans 11 could have interfered in the low correlation value (but significant) obtained since the C18:1trans isomers could not be separated. Hristov et al. (2005) found greater deposition of C18:1trans 10 than C18:1trans 11 in muscle tissue when employing linoleic acid-rich oil in concentrate meal of cattle. Furthermore, the content of C18:1trans obtained (percentage or absolute basis) in our study, was much higher than values obtained in some other studies with animals fed on concentrate (Raes et al., 2001; Nürnberg et al., 2002, 2005; Rule et al., 2002). The reason for the high content of C18:1trans was not clear. It seemed that a considerable amount of PUFA (mainly C18:2n-6 as major FA) could have been converted to cis9, trans11-CLA as first intermediate, and to C18:1trans 11 as next intermediate in rumen environment (Harfoot and Hazlewood, 1997; Demeyer and Doreau, 1999), or to trans10,cis12-CLA as first and to C18:1trans 10 as next intermediate also found in animals fed on high-concentrate diets (Piperova et al., 2002) or vegetable oil-rich concentrate diets (Griinari et al., 1998). And that intestinal absorption of C18:1trans could have been high reflecting the high C18:1trans content of muscle fat (Table 3).

On the other hand, trans10,cis12-CLA isomer appeared in lower content, and it was significantly $(P<0.05)$ higher in double-muscled animals than in the other animal groups. Low correlations were found between CLA individual isomers and carcass measurements. CLA and BFA, both considered minor groups as they represented individually less than $1 \%$ of total FAs, were positively related to the component 2 of the PCA (Fig. 1). Therefore, this component seemed to be related to the origin of muscle FAs as BFA and CLA are of rumen origin (biosynthesis).

Concerning ratios of nutritional interest, $\mathrm{M} / \mathrm{S}, \mathrm{P} / \mathrm{S}, \mathrm{U} /$ $\mathrm{S}$ and n-6/n-3 were calculated (Table 4 ). The influence of genotype on the nutritional value of muscle lipid fraction was evidenced in the results. In general, double-muscled animals, being very lean, nearly approached the current recommendations for $\mathrm{P} / \mathrm{S}$ initially established on 0.45 or higher, and actually, in 1 (reviewed in Simopoulos, 2002), while the other genotypes did not reach the recommendations. The values obtained in AV genotypes $(\mathrm{mh} / \mathrm{mh}, \mathrm{mh} /+,+/+)$ were similar to values obtained in some other studies with Belgian Blue breed and its genotypes (Raes et al., 2001; De Smet et al., 2004). Referring to $\mathrm{M} / \mathrm{S}$ and $\mathrm{U} / \mathrm{S}$ ratios, our animals showed, in general, similar values to other studies (Raes et al., 2001). However, higher $\mathrm{M} / \mathrm{S}$ values are obtained in works carried out with highly fatty breeds (Kazala et al., 1999; Yang et al., 1999; Elías Calles et al., 2000).

The obtained n-6/n-3 ratios were quite high for every biological type, particularly double-muscled animals, showed ratios around 2.5-fold the current recommendation set closed to 4 (Department of Health, 1994; reviewed in Simopoulos, 2002). However, similar high values were obtained in some other studies carried out with German Simmental bulls and German Holstein steers fed on concentrate (Nürnberg et al., 2002). N-6/n-3 ratio of the total lipid fraction of muscle may vary depending on the $n-6 / n-3$ ratio of the phospholipid and triacylglycerol fractions though this ratio is much more affected by feeding regimes of animals than by genetics (Enser et al., 1996; Itoh et al., 1999), and thus, it could be related to the high $\mathrm{n}-6$ content of the concentrate meal given to these animals $(60.4 \% \mathrm{C} 18: 2 \mathrm{n}-6)$. In this sense, the $n-6 / n-3$ ratio obtained in our animals (grain fed domestic beef) is another evidence of the increase of $n-6 /$ n-3 ratio in the food supply of industrialised societies occurred over the last years (reviewed in Simopoulos, 2002).

The obtained prediction equations offer an inexpensive and useful method to assess the FA profile in muscle tissue using carcass conformation and fat cover degree scores as independent variables, and with an acceptable accuracy level for main FA groups. In this sense, we could not find any other studies where these type of equations was examined.

\section{Conclusion}

The results of the study show that breed or genotype affect carcass measurement scores and muscle fatty acid profile through its important effect on animal overall fatness. Homozygous double-muscled animals produce carcasses with high conformation and low IM fat content, with high PUFA proportion. While early-maturing and rustic AM animals produce low yield and high IM fat content, with high SFA and MUFA proportions. Mostly explained by the genotype, it is noteworthy the relationship between carcass measurements and fat quantity and quality, and its practical application using simple and low-cost prediction equations for a rapid and sufficiently accurate main FA group estimation at abattoir level in yearling bulls of Asturian local biological types. 
In general, meat obtained from double-muscled animals display a more appropriate IM fatty acid profile from the nutritional point of view according to actual recommendations, but it could happen the disability of these lean animals to deposit sufficient IM fat to ensure consumer acceptability regarding to other sensorial attributes as flavour and tenderness.

\section{Acknowledgements}

N. Aldai acknowledges a predoctoral fellowship awarded by the Spanish Agricultural Research Institute (INIA) that belongs to Spanish Ministry of Education and Science. The authors would like to thank the staff of Livestock Production Systems of SERIDA for the skilled management of animals and carcasses, and the valuable assistance on sample analysis, and L.J.R. Barrón (UPVEHU, Vitoria, Spain) for his helpful comments.

\section{References}

Aldai, N., Murray, B.E., Nájera, A.I., Troy, D.J., Osoro, K., 2005. Review: derivatisation of fatty acids and its application for conjugated linoleic acid studies in ruminant meat lipids. J. Sci. Food Agric. 85, 1073-1083.

Aldai, N., Murray, B.E., Oliván, M., Martínez, A., Troy, D.J., Osoro, K., Nájera, A.I., 2006a. The influence of breed and mh-genotype on carcass conformation, meat physico-chemical characteristics, and the fatty acid profile of muscle from yearling bulls. Meat Sci. $72,486-495$.

Aldai, N., Osoro, K., Barrón, L.J.R., Nájera, A.I., 2006b. Gas-liquid chromatographic method for analysing complex mixtures of fatty acids including conjugated linoleic acids (cis9trans 11 and trans10cis12 isomers) and long-chain (n-3 or n-6) polyunsaturated fatty acids. Application to the intramuscular fat of beef meat". J. Chromatogr., A 1110, 133-139.

Arthur, P.F., 1995. Double muscling in cattle: a review. Aust. J. Agric. Res. 46, 1493-1515.

Bas, P., Morand-Fehr, P., 2000. Effect of nutritional factors on fatty acid composition of lamb fat deposits. Livest. Prod. Sci. 64, 61-79.

Biagini, D., Lazzaroni, C., 2005. Carcass dissection and commercial meat yield in Piemontese and Belgian Blue double-muscled young bulls. Livest. Prod. Sci. 98, 199-204.

BOE (Boletín Oficial del Estado), 2003. Real Decreto 1698/2003, de 12 de diciembre, por el que se establecen disposiciones de aplicación de los Reglamentos comunitarios sobre el sistema de etiquetado de la carne de vacuno. BOE No. 304, 20th of December 2003, pp. 45345-45350.

Bouton, P.E., Harris, P.V., Shorthose, W.R., 1982. Comparison of some properties of beef from animals homozygous or heterozygous for muscular hypertrophy. Meat Sci. 6, 309-318.

Callow, E.H., 1962. The percentage of fat in the fatty and muscular tissues of steers and the iodine number of the extracted fat, as affected by breed and level of nutrition. J. Agric. Sci. 58, 295-307.

Chang, J.H., Lunt, D.K., Smith, S.B., 1992. Fatty acid composition and fatty acid elongase and stearoyl-CoA desaturase activities in tissues of steers fed high oleate sunflower seed. J. Nutr. 122, 2074-2080.
Chin, S.F., Storkson, J.M., Ha, Y.L., Pariza, M.W., 1992. Dietary sources of conjugated dienoic isomers of linoleic acid, a newly recognized class of anticarcinogens. J. Food Compos. Anal. 185-197.

Clinquart, A., Istasse, L., Dufrasne, I.K., Mayombo, A., Van Eenaeme, C., Bienfait, J.M., 1991. Effects on animal performance and fat composition of two fat concentrates in diets for growing-fattening bulls. Anim. Prod. 53, 315-320.

Clinquart, A., Van Eenaeme, C., Van Vooren, T., Van Hoof, J., Hornick, J.L., Istasse, L., 1994. Meat quality in relation to breed (Belgian Blue vs. Holtein) and conformation (double muscled vs. Dual purpose type. Sci. Aliments 14, 401-407.

Corl, B.A., Baumgard, L.H., Dwyer, D.A., Griinari, J.M., Philips, B.S., Bauman, D.E., 2001. The role of Delta(9)-desaturase in the production of cis-9, trans-11 CLA. J. Nutr. Biochem. 12, 622-630.

De Smet, S., Raes, K., Demeyer, D., 2004. Meat fatty acid composition as affected by fatness and genetic factors: a review. Anim. Res. 53, $81-98$.

Dehority, B.A., 2003. Rumen Microbiology. University Press, Nottingham.

Demeyer, D.I., Doreau, M., 1999. Targets and procedures for altering ruminant meat and milk lipids. Proc. Nutr. Soc. 58, 593-607.

Demeyer, D.I., Buysse, G., Fiems, L., 1995. Meat quality in double muscled animals. In: Lundström, K., Hansson, I., Wiklund, E. (Eds.), Composition of Meat in Relation to Processing, Nutritional and Sensory Quality. ECCEAMST, Utrecht, pp. 95-102.

Department of Health, 1994. Nutritional aspects of cardiovascular disease. Report of the Panel on Dietary Reference Values of the Committee on Medical Aspects of Food Policy. Report on Health and Social Subjects, vol. 46. Her Majesty's Stationery Office, London.

Dewhurst, R.J., Moorby, J.M., Danelón, J., Tweed, J.K., 2002. Effect of diet forage:concentrate ratio on odd-chain fatty acids in milk from Holstein-Friesian cows. J. Dairy Sci. 85, S318.

Duncan, W.R.H., Garton, G.A., 1978. Differences in the proportions of branched-chain fatty acids in subcutaneous triacylglycerols of barley-fed ruminants. Br. J. Nutr. 40, 29-33.

Eichhorn, J.M., Bailey, C.M., Blomquist, G.J., 1985. Fatty acid composition of muscle and adipose tissue from crossbred bulls and steers. J. Anim. Sci. 61, 892-904.

Elías Calles, J.A., Gaskins, C.T., Busboom, J.R., Duckett, S.K., Cronrath, J.D., Reeves, J.J., 2000. Sire variation in fatty acid composition of crossbred Wagyu steers and heifers. Meat Sci. 56, 23-29.

Elmore, J.S., Mottram, D.S., Enser, M., Wood, J.D., 1999. Effect of the polyunsaturated fatty acid composition of beef muscle on the profile of aroma volatiles. J. Agric. Food Chem. 47, 1619-1625.

Enser, M., Hallett, K., Hewitt, B., Fursey, G.A.J., Wood, J.D., 1996. Fatty acid content and composition of English beef, lamb and pork at retail. Meat Sci. 42, 443-456.

Enser, M., Scollan, N.D., Choi, N.J., Kurt, E., Hallett, K., Wood, J.D., 1999. Effect of dietary lipid on the content of conjugated linoleic acid (CLA) in beef muscle. Anim. Sci. 69, 143-146.

Gandemer, G., 1999. Lipids and meat quality: lipolysis, oxidation, Maillard reaction and flavour. Sci. Aliments 19, 439-458.

Goering, H.K., Van Soest, P.J., 1970. Forage fiber analyses (apparatus reagents, procedures and some applications). Agriculture Handbook $\mathrm{N}^{\circ}$ 379. Agriculture Research Service. Unites Status Department of Agricultura.

Griinari, J.M., Dwyer, D.A., McGuire, M.A., Bauman, D.E., Palmquist, D.L., Nurmela, K.V.V., 1998. Trans-octadecenoic acids and milk fat depression in lactating dairy cows. J. Dairy Sci. 81, 1251-1261. 
Griinari, J.M., Corl, B.A., Lacy, S.H., Chouinard, P.Y., Nurmela, K.V.V., Bauman, D.E., 2000. Conjugated linoleic acid is synthesised endogenously in lactating cows by $\Delta^{9}$-desaturase. J. Nutr. 130 , 2285-2291.

Grobet, L., Poncelet, D., Royo, J.L., Brouwers, B., Pirottin, D., Michaux, Ch., Menissier, F., Zanotti, M., Dunner, S., Georges, M., 1998. Molecular definition of an allelic series of mutations disrupting the myostatin function and causing double-muscling in cattle. Mamm. Genome 9, 210-213.

Harfoot, C.G., Hazlewood, G.P., 1997. Lipid metabolism in the rumen, In: Hobson, P.N., Stewart, C.S. (Eds.), The Rumen Microbial Ecosystem, 2nd ed. Blackie Academic \& Professional, New York, pp. 382-425.

Hood, R.L., Allen, C.E., 1975. Bovine lipogenesis: effects of anatomical location, breed and adipose cell size. Int. J. Biochem. 6, 121-131.

Horcada, A., 2001. Manual de Calidad de Carne de Vacuno. Ed. Instituto Técnico y de Gestión Ganadero S.A. y Gobierno de Navarra. Pamplona, Spain, p. 112.

Hristov, A.N., Kennington, L.R., McGuire, M.A., Hunt, C.W., 2005. Effect of diets containing linoleic acid- or oleic acid-rich oils on ruminal fermentation and nutrient digestibility, and performance and fatty acid composition of adipose and muscle tissues of finishing cattle. J. Anim. Sci. 83, 1312-1321.

Huerta-Leidenz, N.O., Cross, H.R., Savell, J.W., Lunt, D.K., Baker, J.F., Pelton, L.S., Smith, S.B., 1993. Comparison of the fatty acid composition of subcutaneous adipose tissue from mature Brahman and Hereford cows. J. Anim. Sci. 71, 625-630.

INTERNATIONAL STANDARD ISO 1443-1973. Meat and meat products. Determination of total fat content.

Itoh, M., Johnson, C.B., Cosgrove, G.P., Muir, P.D., Purchas, R.W., 1999. Intramuscular fatty acid composition of neutral and polar lipids for heavy-weight Angus and Simmental steers finished on pasture or grain. J. Sci. Food Agric. 79, 821-827.

Kazala, E.C., Lozeman, F.J., Mir, P.S., Laroche, A., Bailey, D.R.C., Weselake, R.J., 1999. Relationship of fatty acid composition to intramuscular fat content in beef from crossbred Wagyu cattle. J. Anim. Sci. 77, 1717-1725.

Kosulwat, S., Greenfield, H., James, J., 2003. Lipid composition of Australian retail lamb cuts with differing carcass classification characteristics. Meat Sci. 65, 1413-1420.

Laborde, F.L., Mandell, I.B., Tosh, J.J., Wilton, J.W., BuchananSmith, J.G., 2001. Breed effects on growth performance, carcass characteristics, fatty acid composition, and palatability attributes in finishing steers. J. Anim. Sci. 79, 355-365.

Lawless, F., Stanton, C., L'Escop, P., Devery, R., Dillon, P., Murphy, J.J., 1999. Influence of breed on bovine milk cis-9, trans-11-conjugated linoleic. Livest. Prod. Sci. 62, 43-49.

Leth, T., Ovesen, L., Hansen, K., 1998. Fatty acid composition of meat from ruminants, with special emphasis on trans fatty acids. JAOCS 75, 1001-1005.

Lo Fiego, D.P., Santoro, P., Macchioni, P., De Leonibus, E., 2005. Influence of genetic type live weight at slaughter and carcass fatness on fatty acid composition of subcutaneous adipose tissue of raw ham in the heavy pig. Meat Sci. 69, 107-114.

Malau-Aduli, A.E.O., Edriss, M.A., Siebert, B.D., Bottema, C.D.K., Pitchford, W.S., 2000. Breed differences and heterosis in triacylglycerol fatty acid composition of bovine adipose tissue. J. Anim. Physiol. Anim. Nutr. 83, 106-112.

Mandell, I.B., Buchanan-Smith, J.G., Holub, B.J., Campbell, C.P., 1997. Effect of fish meal in beef cattle diets on growth performance, carcass characteristics and fatty acid composition of longissimus muscle. J. Anim. Sci. 75, 910-919.
Marschall, D.M., 1999. Genetics of meat quality. In: Fries, R., Ruvinsky, A. (Eds.), The Genetics of Cattle. CAB International, Wallingford, UK, pp. 605-636.

Martínez, A., García, P., García, U., Menéndez, J., Castro, P., Osoro, K., 2003. Diferencias en los crecimientos y características de la canal según la presencia del gen de la hipertrofia muscular. Información Técnica Económica Agraria (ITEA), vol. extra 24. Zaragoza, Spain, pp. 58-60.

Mazier, M.J.P., Jones, P.J.H., 1991. Dietary fat quality and circulating cholesterol levels in humans: a review of actions and mechanisms. Progr. Food Nutr. Sci. 15, 21-41.

Mossoba, M.M., Kramer, J.K.G., Yurawecz, M.P., Sehat, N., Roach, J.A.G., Eulitz, K., Fritsche, J., Dugan, M.E.R., Ku, Y., 1999. Impact of novel methodologies on the analysis of conjugated linoleic acid CLA. Implications of CLA feeding studies. Feet/ Lipid 101, S235-S243.

Nürnberg, K., Wegner, J., Ender, K., 1998. Factors influencing fat composition in muscle and adipose tissue of farm animals. Livest. Prod. Sci. 56, 145-156.

Nürnberg, K., Ender, B., Papstein, H.J., Wegner, J., Ender, K., Nürnberg, G., 1999. Effects of growth and breed on the fatty acid composition of the muscle lipids in cattle. Z. Lebensm.-Unters.Forsch. A 208, 332-335.

Nürnberg, K., Nüernberg, G., Ender, K., Lorenz, S., Winkler, K., Rickert, R., Steinhart, H., 2002. n-3 fatty acids and conjugated linoleic acids of longissimus muscle in beef cattle. Eur. J. Lipid Sci. Technol. 104, 463-471.

Nürnberg, K., Dannenberger, D., Nürnberg, G., Ender, K., Voigt, J., Scollan, N.D., Wood, J.D., Nuter, G.R., Richardson, R.I., 2005. Effect of a grass-based and a concentrate feeding system on meat quality characteristics and fatty acid composition of longissimus muscle in different cattle breeds. Livest. Prod. Sci. 94, 137-147.

OJEC, 1981a. Council Regulation (EEC) No 1208/81 of 28 April 1981 Determining the Community Scale for the Classification of Carcasses of Adult Bovine Animals. Official Journal, L123, p. 3. 7.5.1981.

OJEC, 1981b. Commission Regulation (EEC) No 2930/81 of 12 October 1981 Adopting Additional Provisions for the Application of the Community Scale for the Classification of Carcasses of Adult Bovine Animals. Official Journal, L293, p. 6. 13.10.1981.

OJEC, 1991a. Council Regulation (EEC) No 1026/91 of 22 April 1991 Amending Regulation (EEC) No 1208/81 Determining the Community Scale for the Classification of Carcasses of Adult Bovine. Official Journal, L106, pp. 0002-0003. 26/04/1991.

OJEC, 1991b. Commission Regulation (EEC) No 2237/91 of 26 July 1991 Amending Regulation (EEC) No 2930/81 Adopting Additional Provisions for the Application of the Community Scale for the Classification of Carcasses of Adult Bovine Animals. Official Journal, L204, pp. 0011-0012. 27/07/1991.

Oliván, M., Martínez, A., García, P., Noval, G., Osoro, K., 1999. Estimation of the carcass composition of yearling bulls of "Asturiana de los Valles" breed from the dissection of a rib joint. Meat Sci. 57, 185-190.

Oliván, M., de la Roza, B., Mocha, M., Martínez, M.J., 2002. Prediction of physico-chemical and texture characteristics of beef by near infrared transmittance spectroscopy. Proceedings of the 10th International Conference of Near Infrared Spectroscopy, pp. 197-202.

Oliván, M., Martínez, A., Osoro, K., Sañudo, C., Panea, B., Olleta, J.L., Campo, M.M., Oliver, M.A., Serra, X., Gil, M., Piedrafita, J., 2004. Effect of muscular hypertrophy on physico-chemical, biochemical and texture traits of meat from yearling bulls. Meat Sci. 68, $567-575$. 
Osoro, K., Martínez, A., Castro, P., 2003. Desarrollo de Sistemas Eficientes de Producción de Carne de Calidad en Zonas Bajas. KRK Ediciones (SERIDA), Oviedo, Spain.

Palmquist, D.L., Santora, J.E., 1999. Endogenous synthesis of rumenic acid in rodents and humans. In: Yurawecz, M.P., Mossoba, M.M., Kramer, J.K.G., Pariza, M.W., Nelson, G.J. (Eds.), Advances in Conjugated Linoleic Acid Research. AOCS Press, Champaign, Illinois, pp. 201-208.

Piedrafita, J., Quintanilla, R., Sañudo, C., Panea, B., Olleta, J.L., Campo, M.M., Panea, B., Renand, G., Turin, F., Jabet, S., Osoro, K., Oliván, M.C., Noval, G., García, P., García, M.D., Oliver, M.A., Guispert, M., Serra, X., Espejo, M., García, S., López, M., Izquierdo, M., 2003. Carcass quality of 10 beef cattle breeds of the Southwest of Europe in their typical production systems. Livest. Prod. Sci. 82, 1-13.

Piperova, L.S., Sampugna, J., Teter, B.B., Kalscheur, K.F., Yurawecz, M.P., Ku, Y., Morehouse, K.M., Erdman, R.A., 2002. Duodenal and milk trans octadecenoic acid and conjugated linoleic acid (CLA) isomers indicate that postabsorptive synthesis is the predominant source of cis-9-containing CLA in lactating dairy cows. J. Nutr. 132, 1235-1241.

Purchas, R.W., Knight, T.W., Busboom, J.R., 2005. The effect of production system and age on concentrations of fatty acids in intramuscular fat of the longissimus and triceps brachii muscles of Angus-cross heifers. Meat Sci. 70, 597-603.

Raes, K., De Smet, S., Demeyer, D., 2001. Effect of double-muscling in Belgian Blue young bulls on the intramuscular fatty acid composition with emphasis on conjugated linoleic acid and polyunsaturated fatty acids. Anim. Sci. 73, 253-260.

Raes, K., De Smet, S., Balcaen, A., Claeys, E., Demeyer, D., 2003. Effects of diets rich in n-3 polyunsaturated fatty acids on muscle lipids and fatty acids in Belgian Blue double-muscled young bulls. Reprod. Nutr. Dev. 43, 331-345.

Robelin, J., Geay, Y., 1975. Estimation de la composition de la carcasse des taurillons à partir de la composition de la 6ème côte. Bulletin Techniquel Centre de Recherche Zootechnique et Vétérinaires de Theix. INRA 22, 41-44.

Robertson, J.B., Van Soest, P.J., 1981. The detergent system of analysis and its application to human foods. In: James, W.P.J., Theader, O. (Eds.), The Analysis of Dietary Fibre of Food. Dekker, New York, pp. 123-158.

Rule, D.C., Smith, S.B., Romans, J.R., 1995. Fatty acid composition of muscle and adipose tissue of meat animals. In: Smith, S.B., Smith, D.R. (Eds.), Biology of Fat in Meat Animals. Current Advances Series of the American Society of Animal Science. Champaign, IL, pp. 144-165.

Rule, D.C., Broughton, K.S., Shellito, S.M., Maiorano, G., 2002. Comparison of muscle fatty acid profiles and cholesterol concentrations of bison, beef cattle, elk, and chicken. J. Anim. Sci. 80, 1202-1211.

Siebert, B.D., Pitchford, W.S., Kruk, Z.A., Kuchel, H., Deland, M.P.B., Bottema, C.D.K., 2003. Differences in $\Delta^{9}$ desaturase activity between Jersey- and Limousin-sired cattle. Lipids 38, 539-543.

Simopoulos, A.P., 1991. Omega-3 fatty acids in health and disease and in growth and development. Am. J. Clin. Nutr. 54, 438-463.
Simopoulos, A.P., 2002. The importance of the ratio of omega-6/ omega-3 essential fatty acids. (Dosier: Polyunsaturated fatty acids in biology and diseases). Biomed. Pharmacother. 56, 365-379.

SPSS, Inc., 2002. Guía Breve. SPSS 11.5, Ireland.

TECATOR, 1991. Application Note, AN 92/87. Determination of Total Fat in Feed and Plant Materials.

TECATOR, 1995. Application Note, AN 300. The Determination of Nitrogen According to Kjeldahl Using Block Digestion and Steam Destillation. Perstoorp Analytical.

TECATOR, 2001. Application Note, AN 30001. Determination of crude protein (Kjeldahl Nitrogen) in Animal Feed, Forage (Plant Tissue), Grain and Oilseeds Using Block Digestion with Copper Catalyst and Steam Distillation into Boric Acid.

Truscott, T.G., Wood, J.D., Denny, H.R., 1983. Fat deposition in Hereford and Friesian steers. 2. Cellular development of the major fat depots. J. Agric. Sci., Camb. 100, 271-276.

Ulbricht, T.L.V., Southgate, D.A.T., 1991. Coronary heart disease: seven dietary factors. Lancet 338, 985-992.

Uytterhaegen, L., Claeys, E., Demeyer, D., Lippens, M., Fiems, L.O., Boucqué, C.C., Van de Voorde, G., Bastiaens, A., 1994. Effects of double-muscling on carcass quality, beef tenderness and myofibrillar protein degradation in Belgian Blue White bulls. Meat Sci. 38, 255-267.

Van Der Meer, J.M., 1983. C. E. C. Workshop on methodology of feedingstuffs for ruminants. European in Vitro Ringtest Statistical Report Ins. Voor Veevoedingsonderzoek (I. V.V.O). The Netherlands. Concep Report, vol. 155, p. 36.

Van Es, A.J.H., Van Der Meer, J.M., 1980. Methods of Analysis for Predicting the Energy and Protein Value of Feeds for Farm Animals. Institute for Livestock Feedeing and Nutrition Research Delystad, The Netherlands, pp. 6-74.

Van Soest, P.J., Robertson, J.B., Lewis, B.A., 1991. Methods for dietary, neutral detergent fiber and non starch polysaccharides in relation to animal nutrition. J. Dairy Sci. 74, 3583-3597.

Vlaeminck, B.M., Bruinenberg, H., Fievez, V., Raes, K., Demeyer, D., 2002. Effect of crude fibre content in grass silage on milk oddchain fatty acids. Reprod. Nutr. Dev. 42, S71 (Abstr.).

Wheeler, T.L., Shackelford, S.D., Casas, E., Cundiff, L.V., Koohmaraie, M., 2001. The effects of Piedmontese inheritance and myostatin genotype on the palatability of longissimus thoracis, gluteus medius, semimembranosus, and biceps femoris. J. Anim. Sci. 79, 3069-3074.

Wolff, R.L., 1995. Content and distribution of trans-18:1 acids in ruminant milk and meat fats. Their importance in European diets and their effect on human milk. JAOCS 72, 259-272.

Wood, J.D., Enser, M., Fisher, A.V., Nuter, R.I., Richardson, R.I., Sheard, P.R., 1997. Manipulating meat quality and composition. Proc. Nutr. Soc. 58, 363-370.

Wright, I.A., Russel, A.J.F., 1984. Partition of fat, body composition and body condition score in mature cows. Anim. Prod. 38, 23-32.

Yang, A., Larsen, T.W., Powell, V.H., Tume, R.K., 1999. A comparison of fat composition of Japanese and long-term grainfed Australian steers. Meat Sci. 51, 1-9. 